\title{
Re-evaluation of the age of some dinosaur localities from the southern Pyrenees by means of megaloolithid oospecies
}

\author{
A.G. Sellés ${ }^{1}$, B. Vila ${ }^{1,2 *}$ \\ ${ }^{1}$ Institut Català de Paleontologia Miquel Crusafont, Carrer de l'Escola Industrial, 23, 08201, Sabadell, Spain. \\ ${ }^{2}$ Grupo Aragosaurus-IUCA, Paleontología, Facultad de Ciencias, Universidad de Zaragoza, Calle Pedro Cerbuna, \\ 12, 50009 Zaragoza, Spain \\ e-mail addresses: albert.garcia@icp.cat (A.G.S.); bernat.vila@unizar.es (B.V., *corresponding author)
}

Received: 19 December 2013 / Accepted: 18 December 2014 / Available online: 25 March 2015

\begin{abstract}
Since the beginning of the 20th Century the Upper Cretaceous continental and transitional marine deposits of the southern Pyrenees have produced more than 220 dinosaur fossil localities. New discoveries and advances in magnestostratigraphy and biostratigraphy provide a robust biostratigraphical framework for the latest Cretaceous dinosaur faunas in the region, although the age of some localities has remained uncertain. Here, we re-evaluate the age of some classic and new dinosaur fossil localities on the basis of the potential dating of megaloolithid oospecies and provide parataxonomic and age data for twenty-three localities with new megaloolithid egg fossils. Further, we review the nomenclature and probable synonymies of several of the most historically significant localities in the southern Pyrenees. With the new age assignments proposed for some significant localities (Basturs, Orcau-1, Els Nerets, Figuerola-2, Suterranya-1), we claim that in the southern Pyrenees a) the ankylosaurian dinosaurs survived beyond the early Maastrichtian-late Maastrichtian boundary and coexisted with hadrosauroids; b) the theropod record is scarce in the early Maastrichtian and the taxonomic diversity (richness) of theropods is notably higher in the late Maastrichtian; and c) the megaloolithid egg record assigned to sauropods is continuous through the entire Maaastrichtian but is scarce in the Upper Campanian.
\end{abstract}

Keywords: dinosaurs, biostratigraphy, Late Cretaceous, Pyrenees, Megaloolithus

\section{Resumen}

Desde principio del siglo XX los depósitos continentales y de transición de los Pirineos meridionales han producido más de 220 localidades con fósiles de dinosaurios. Los nuevos descubrimientos y los avances en magnetostratigrafía y biostratigrafía han proporcionado un robusto esquema biostratigráfico de las faunas finicretácicas de dinosaurios en la región, a pesar de que la edad de algunas localidades permanecía incierta. En el presente trabajo reevaluamos la edad de algunas localidades clásicas y nuevas con fósiles de dinosaurios en base al potencial de datación de las oospecies megaloolítidas y aportamos datos parataxonómicos y de edad para veintitrés localidades con nuevos fósiles de huevos megaloolítidos. Además, revisamos la nomenclatura y las probables sinonimias de varias de las localidades históricamente más significativas de los Pirineos meridionales. Con las nuevas asignaciones de edad propuestas en algunas localidades significativas (Basturs, Orcau-1, Els Nerets, Figuerola-2, Suterranya-1) se establece que en los Pirineos meridionales a) los dinosaurios anquilosaurios sobrepasaron el límite entre el Maastrichtiense inferior y superior y coexistieron con los hadrosauroideos; b) el registro de terópodos es escaso en el Maastrichtiense inferior siendo remarcablemente más elevado en el Maastrichtiense superior; y c) el registro de huevos megaloolítidos asignados a saurópodos es continuo en todo el Maastrichtiense pero escaso en el Campaniense superior.

Palabras clave: dinosaurios, biostratigrafía, Cretácico Superior, Pirineos, Megaloolithus

\section{Introduction}

Areas of the present-day Pyrenees (southern France and north-eastern Spain) contain localities ranging from the late Campanian to the latest Maastrichtian, providing a produc- tive succession of dinosaur fossil remains from the latest Cretaceous (Buffetaut and Le Loeuff, 1991; López-Martínez et al., 2001; Laurent et al., 2002; Riera et al., 2009). In the last century more than two hundred localities have been discovered in the southern Pyrenees. Mr. Bartolomé Castell made 
the first isolated findings in 1927 in the vicinity of Tremp (Marín and Bataller, 1929); these were followed by further prospects and geological field characterizations that yielded additional material from localities such as "Orcau", "Suterraña" and "Bastús" (Lapparent and Aguirre, 1956; Lapparent, 1958). In the early 1980s and 1990s more localities were described, including significant bone, egg and track localities such as Els Nerets, Sant Romà d'Abella, Fumanya and Fontllonga (Casanovas-Cladellas and Santafé-Llopis, 1993; Casanovas-Cladellas et al., 1985, 1993; Le Loeuff and Martínez, 1997; López-Martínez et al., 1998). Since then, various authors have compiled the fossil localities containing dinosaurs (López-Martínez, 2003; Vila et al., 2006; Suñer et al., 2008, Riera et al., 2009), and at present the total number of localities is about 220. The stratigraphic age for these continental dinosaur-bearing localities has traditionally been provided by stratigraphic correlation with marine series (Ardèvol et al., 2000) and magnetostratigraphy (Galbrun et al., 1993), together with the use of various biostratigraphic markers (charophytes, palynomorphs, rudists; Feist and Colombo, 1983; Médus et al., 1992; Riveline et al., 1996; Vicens et al., 2004). In the last decade, the profusion of new discoveries and the advances in magnetostratigraphy and biostratigraphy in the southern Pyrenees (López-Martínez et al., 2001; Oms et al., 2007; Pereda-Suberbiola et al., 2009; Riera et al., 2009; Prieto-Márquez et al., 2013; Vila et al., 2012, 2013) have allowed a more precise and robust correlation for these localities. Of special interest is the calibration of the succession of megaloolithid oospecies with the magnetostratigraphic scale (Garcia and Vianey-Liaud, 2001; Vila et al., 2011).

The aim of the present work is to re-evaluate the age of 20 historically significant localities by means of the use of oospecies and other biochronostratigraphic criteria and to provide age and parataxonomic data for 23 localities that yield new megaloolithid egg material. Further, we provide a review of the nomenclature and probable synonymies of 18 of the dinosaur localities in the southern Pyrenees.

\section{Geological setting}

The southern Pyrenees (NE Iberian Peninsula; Fig. 1) contain a 3000-m-thick succession of sedimentary rocks encompassing the transition from shallow marine carbonate platforms to fully continental environments (Riera et al., 2009 and references therein). Two main geological units of latest Cretaceous age (late Campanian to late Maastrichtian) are recognized in the area: the Arén Sandstone Fm. and the Tremp Fm. The Arén Sandstone Fm. is composed of sandstones deposited in beach, barrier-island and deltaic systems; it passes gradually to the Tremp Fm. by a diachronic interfingering of strata (Díaz-Molina, 1987). The Tremp Formation has been divided informally into four lithologic units (Rosell et al., 2001): 1) the "grey unit", 2) the "lower red unit", 3) the "Vallcebre Limestones and laterally equivalent strata", and 4) the "upper red unit".
The localities discussed in the present work are situated in distinct areas of the provinces of Barcelona and Lleida; from east to west these are: the Vallcebre, Coll de Nargó, Tremp and Àger synclines. In these areas, the deposits of late Campanian to latest Maastrichtian age have yielded a diverse and abundant tetrapod fossil record that comprises dinosaurs (sauropods, theropods, ornithopods and ankylosaurs; LópezMartínez et al., 2001; Riera et al., 2009; Pereda-Suberbiola et al., 2009; Cruzado-Caballero et al., 2010; Vila et al., 2012; Prieto-Márquez et al., 2013; Torices et al., in press), pterosaurs (Dalla Vecchia et al., 2013), crocodilians (Puértolas et al., 2011; Puértolas-Pascual et al., 2014), turtles (Marmi et al., 2012), and amphibians and squamate reptiles (Blain et al., 2010).

\section{Methods and materials}

We have reviewed the names of 18 south-Pyrenean localities and standardized with the current toponymy, correcting previous misspellings and providing name equivalences. When possible, the criterion followed for assigning the name to a locality has been its primary citation in the literature. Many localities have received different names after their first being reported and in cases where the secondary name has been cited more frequently in the literature, we have chosen to maintain the more extensively used name. If, after the review and name standardization, the locality name coincides with a previous naming we have added numerals in order to avoid misunderstandings. Regarding terminology, we used "locality" to refer a discrete area or stratigraphic section where fossils occur and which may or may not include various sites. A "site" refers to a discrete fossil-bearing level within a locality.

The new eggshell fragments described in the present study (Appendix 1) were collected from both classic and unreported localities in the southern Pyrenees (Fig. 1). These fossil remains were treated with potassium hydroxide $(\mathrm{KOH})$ and/or sodium hexametaphosphate (SHMP) 30\%, and cleaned in an ultrasonic bath (Val et al., 2014). Samples were preliminarily analyzed using the Leica ${ }^{\circledR}$ M60 binocular, and structural characters (e.g. shell thickness, ornamental pattern, pore aperture width) were measured using Leica ${ }^{\circledR}$ Application Suite 2.8.1 software. Several samples were prepared as standard thin sections ( $30 \mu \mathrm{m}$-thick) while others were examined and photographed using the electronic microscope ESEM Quanta 200 FEI, XTE 325/D8395, in the Department of ScientificTechnical Services of the Universitat de Barcelona. Eggshells were identified in terms of parataxonomy following Mikhailov (1997).

The studied material is housed in the collection of the Institut Català de Paleontologia (IPS-58959, 58960, 58963 to 58965, 58967, 58968, 58975, 58982, 58987, 58992, 59132 to $59135,59137,82173$ to 82180,82182 to 82227,82230 to 82270).

Institutional abbreviation: IPS, Institut de Paleontologia de Sabadell. 

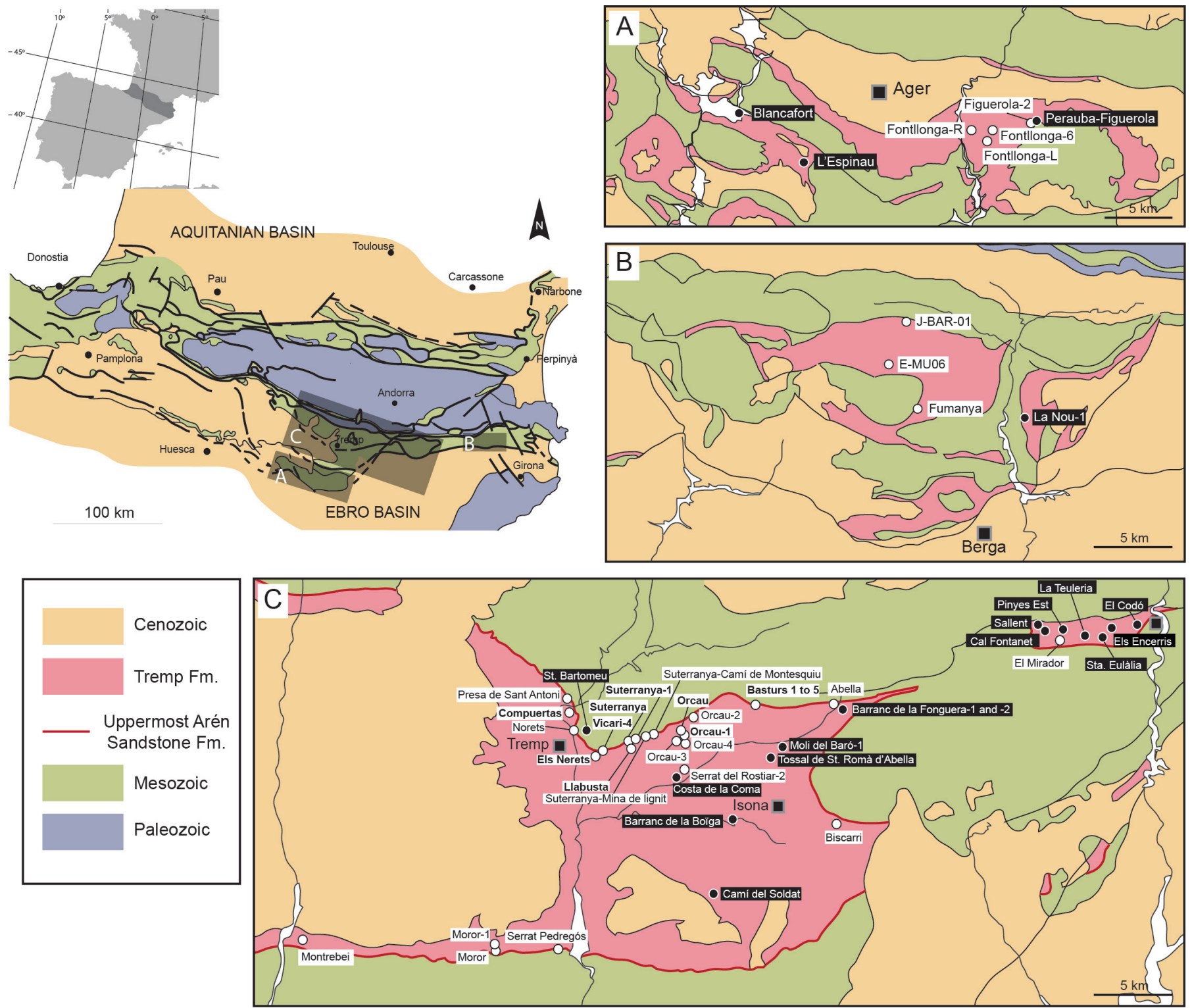

Fig. 1.- Geographical and geological location of the latest Cretaceous outcrops and localities studied or mentioned in the present work. A) Àger syncline, B) Vallcebre syncline, C) Coll de Nargó and Tremp synclines. The location of the Fontllonga L, Norets, Suterranya, and Compuertas is approximative. Names in white square: known localities. Names in black square: new eggshell localities. Names in bold: indicate localities that have changed its age after this review.

\section{Results}

\subsection{Historical review of the nomenclature and synonymies of some dinosaur localities}

Since the earliest dinosaur discoveries in the southern Pyrenees various authors have published data on particular localities, sometimes generating a number of different names or spellings for the same locality. It is out of the scope of the present work to review the nomenclature of all the southern Pyrenean localities, but in order to avoid further misunderstandings in some of the cases, we here discuss and standardize their name and synonymy (Table 1).

Several dinosaur remains were recovered in the area around the villages of Talarn, Suterranya and Orcau (Tremp Basin).
Lapparent and Aguirre (1956) reported various fossil localities in the basal levels of the "grey unit" of the Tremp Formation in this area (Pereda-Suberbiola and Ruiz-Omeñaca, 2012). The Presa de San Antonio locality reported by Lapparent and Aguirre (1956, p. 379) is situated near the village of Talarn and is probably equivalent to Sant Antoni-2 referred to Ardèvol et al. (1995), which was later named Presa de Tremp by Vila et al. (2012). The locality may correspond to that described by Bartolomé Castell in 1927 (Marín and Bataller, 1929). Southwards, the Norets locality referred to PeredaSuberbiola et al. (2003) is equivalent to the Point 2 of Lapparent and Aguirre (1956, p. 380). The Els Nerets locality, originally referred to Casanovas-Cladellas et al. (1985), is equivalent to Vilamitjana-1 (V-1) of Ardèvol et al. (1995). It is also worth noting that the eggshell locality Vicari referred 


\begin{tabular}{|c|c|}
\hline Locality name & Previous names and equivalences \\
\hline Presa de Sant Antoni & $\begin{array}{l}\text { "Presa de San Antonio" or Point } 1 \text { of Lapparent and Aguirre (1956, p. 379), "Sant Antoni-2" } \\
\text { of Ardèvol et al. (1995), Presa de Tremp after Vila et al. (2012). }\end{array}$ \\
\hline Norets after Pereda-Suberbiola et al. (2003) & Point 2 of Lapparent and Aguirre (1956, p. 380) \\
\hline $\begin{array}{l}\text { Els Nerets after Casanovas-Cladellas et al. } \\
\text { (1985) }\end{array}$ & V-1 (Vilamitjana-1) of Ardèvol et al. (1995) \\
\hline Suterranya-Camí de Montesquiu & Point 3 of Lapparent and Aguirre (1956, p. 380) \\
\hline Suterranya-Mina de lignit & Point 4 of Lapparent and Aguirre (1956, p. 380), "Suterranya" of Escaso et al. (2010) \\
\hline Suterranya & "Suterraña" of Moratalla (1993) \\
\hline Suterranya-1 after Ardèvol et al. (1995) & "L'Abeller" of Prieto-Márquez et al. (2000),"Suterraña" of Torices et al. (in press) \\
\hline Orcau-1 after Ardèvol et al. (1995) & "Orcau" of Lapparent and Aguirre (1956) \\
\hline Orcau-2 after Ardèvol et al. (1995) & "Orcau" of Llompart et al. (1984) \\
\hline Orcau after Moratalla (1993) & - \\
\hline Moror & "Moró" of Brinkmann (1984) \\
\hline Moror-1 & $\begin{array}{l}\text { "Moro" of Vianey-Liaud and López-Martínez (1997), López-Martínez (2000) and Bravo } \\
\text { and Marugán-Lobón (2013) }\end{array}$ \\
\hline $\begin{array}{l}\text { Serrat Pedregós after López-Martínez and } \\
\text { Vicens (2012) }\end{array}$ & Cellers-2 of López-Martínez (2000) \\
\hline Montrebei after López-Martínez, (2000) & misspelled "Montrebey" in Torices Hernández (2002) \\
\hline $\begin{array}{l}\text { Fontllonga-6 after Vianey-Liaud and López- } \\
\text { Martínez (1997) }\end{array}$ & "Fontllonga" of Casanovas-Cladellas and Santafé-Llopis (1993) \\
\hline Fontllonga L after Moratalla (1998) & "Fontllonga" of Moratalla (1993) \\
\hline Fontllonga of Casanovas et al. (1999) & "Fontllonga R" of López-Martínez (2003) \\
\hline Santa Eulàlia-1 to -4 & misspelled "Santa Eulària” in López-Martínez (2000) \\
\hline
\end{tabular}

Table 1.- Nomenclature and synonymies of some of the south-Pyrenean dinosaur localities discussed in the present work.

to by Moratalla (1993, 1998) and López-Martínez (2000) may be equivalent to the Vicari-4 locality of Torices Hernández (2002) and Torices et al. (2004, 2012).

In the vicinity of the village of Suterranya, up to four localities were distinguished. The first locality, here named "Suterranya-Camí de Montesquiu" (Point 3 of Lapparent and Aguirre, 1956, p. 380), was discovered by Walter Georg Kühne in 1954 and yielded several dinosaur bones of indeterminate affinity. The second locality, here named "Suterranya-Mina de lignit" (Point 4 of Lapparent and Aguirre, 1956, p. 380), was discovered by Josep Montané and yielded mainly fragmentary dinosaur bones currently housed in the Museo Nacional de Ciencias Naturales (MNCN) in Madrid. After conversations with Josep Montané and revision of the MNCN collections, we could claim that this latter locality probably yielded the ankylosaur bones reported by Escaso et al. (2010) as well as other fragmentary bones of sauropod affinity. In addition, Moratalla (1993) reported dinosaur eggshells from the Suterranya locality (originally spelled "Suterraña"); finally, Ardèvol et al. $(1995,1999)$ reported the egg locality of Suterranya-1, which is a synonym of the L'Abeller locality reported by Prieto-Márquez et al. (2000) and "Suterraña" of Torices et al. (in press); this also yielded an isolated theropod tooth.

At least five dinosaur localities have been reported in the vicinity of the village of Orcau. Lapparent and Aguirre (1956) distinguished four localities with dinosaur remains, the most important being that of "Orcau" discovered by W.G. Kühne in 1954 and containing various sauropod bones. Llompart et al. (1984) described dinosaur tracks east of the village of Orcau. Ardèvol et al. (1995) renamed the bone and track localities as Orcau-1 and Orcau-2, respectively. Riera et al. (2009) and Vila et al. (2013) followed the same procedure for naming the localities of Orcau-3 (bones) and Orcau-4 (tracks), respectively. Finally, Moratalla $(1993,1998)$ reported dinosaur eggshells from a locality called Orcau.

At the southern margin of the Tremp Basin, Brinkmann (1984) described dinosaur remains in the Moror locality (misspelled "Moró"); some years later, Vianey-Liaud and López-Martínez (1997) and subsequent works (López-Martínez, 2000; Bravo and Marugán-Lobón, 2013) referred to an egg locality as "Moro" (we here correct the misspelling and change the name to Moror-1 for the sake of distinction). López-Martínez and Vicens (2012) also described the Serrat Pedregós egg locality, which is equivalent to the Cellers-2 locality referred to by the same authors some years before (López-Martínez, 2000). The latter author also reported the Montrebei eggshell and tooth locality (misspelled "Montrebey" by Torices Hernández, 2002).

In the Àger syncline, various authors reported dinosaur remains from at least three localities with similar names. The first locality reported in the literature was "Fontllonga" (Casanovas-Cladellas and Santafé-Llopis, 1993), which is the same locality later reported by Vianey-Liaud and LópezMartínez (1997) and subsequent works as Fontllonga-6. In the same year Moratalla (1993) gave the name "Fontllonga" (later named "Fontllonga L"; Moratalla, 1998) to a locality with dinosaur eggshells. Another locality in the area, also 
named "Fontllonga" (Casanovas et al., 1999) and yielding a hadrosaur dentary, is a synonym of "Fontllonga R" of LópezMartínez (2003).

In the Coll de Nargó syncline, López-Martínez (2000) reported "several superposed levels with scattered clutches" in the area of "Santa Eulària", which probably correspond to the sites of Santa Eulàlia-1 to -4 (we have corrected the misspelling), sampled in the present work (Appendix 1).

\subsection{Parataxonomical study}

The parataxonomical study of dinosaur eggshells collected in new and classical localities of the southern Pyrenees allows them to be attributed to four megaloolithid oospecies: Megaloolithus aureliensis, M. siruguei, M. mamillare and M. baghensis (see Appendix 2 for further data and discussion). The studied sample includes 2738 eggshell fragments from in situ complete eggs, eggshell accumulations (egg debris) and scattered eggshells (Appendix 1). Most eggshells occur in overbank deposits associated with fluvial or lagoonal systems, in grey to reddish mudstones and marls, or in limestones associated with lacustrine settings.

\section{Discussion}

\subsection{Review and update of the age of some dinosaur localities}

Some authors have argued that dinosaur eggshells can be used as biochronological markers in continental deposits (Garcia and Vianey-Liaud, 2001). This idea, originally proposed for the Aix Basin in Provence (France), has been successfully exported to the southern Pyrenees regions of Vallcebre and Coll de Nargó (Vila et al., 2011; Sellés et al., 2013). The oospecies assemblages (properly named oozones, see Sellés et al., 2013) are calibrated with magnetochrons and indicate restricted temporal ranges for the megaloolithid oospecies (Fig. 2). For instance, the dominance of M. siruguei (together with the oospecies M. aureliensis and Cairanoolithus) mainly indicates a late Campanian to early Maastrichtian age; its replacement with Megaloolithus mamillare occurs around the $\mathrm{C} 31 \mathrm{r}-\mathrm{C} 31 \mathrm{n}$ polarity change; and the appearance of M. mamillare and/or M. baghensis (formerly $M$. pseudomamillare, Vianey-Liaud et al., 2003) indicates a late Maastrichtian age (Garcia and Vianey-Liaud, 2001; Vila et al., 2011; Sellés et al., 2013).

In the present work, the use of oozones based on megaloolithid oospecies enables the re-evaluation of the age of several localities (Fig. 2A). In the eastern part of the Tremp Basin, the Biscarri egg locality yielded the oospecies Megaloolithus siruguei and was originally referred to the late Campanian (López-Martínez et al., 2000). This oospecies is represented in Oozone 1, which is of late Campanian-early Maastrichtian age (Garcia and Vianey-Liaud, 2001), but also on its own in Oozone 2, of early Maastrichtian age (Garcia and VianeyLiaud, 2001; Vila et al., 2011). The new magnetostratigraphic correlations of lower Tremp Formation units in the Tremp Basin (Vila et al., 2012) indicate that the basal part of the formation is probably early Maastrichtian in age and thus the Biscarri locality (together with the Barranc de la Fonguera locality; Appendix 1) would be early Maastrichtian in age.

At the north-western margin of the Tremp Basin the age of the localities of Basturs, Orcau-1, Els Nerets, Orcau, Llabusta, Vicari, Compuertas, Suterranya, Suterranya-1, and Abella has been re-evaluated (Appendix 1). Basturs (originally spelled "Bastus" by Lapparent, 1958) was the first egg locality to be discovered in the southern Pyrenees. This nesting area refers to various egg levels (the egg-bearing sites of Basturs-1, Basturs- 2, Basturs-4, and Basturs-5; Ardèvol et al., 1999) and was considered early Danian by Lapparent (1958), Maastrichtian by Moratalla (1993), "upper Rognacian" by Vianey-Liaud and López-Martínez (1997), and late Campanian by López-Martínez (2000) and Díaz-Molina et al. (2007). Moratalla (1993, 1998) and Vianey-Liaud and López-Martínez (1997) reported the oospecies M. mamillare in the Basturs-1 and Basturs-2 sites, and therefore they are here considered late Maastrichtian in age.

At the end of 1954 W.G. Kühne discovered the bone locality of Orcau-1 (originally named "Orcau" by Lapparent and Aguirre, 1956). These authors and Casanovas et al. (1987) referred the age of the locality to the Maastrichtian. Casanovas-Cladellas et al. (1985) reported the locality of Els Nerets (Tremp, Lleida), which was considered Maastrichtian in age. López-Martínez (2000) dated it as late Campanian, and most recently Dalla Vecchia et al. (2014) have suggested a late Maastrichtian age on the basis of the stratigraphic correlation of Riera et al. (2009) but with no further biostratigraphic constraints. Recent prospects and excavations in the Orcau-1 and Els Nerets localities indicate that they bear Megaloolithus baghensis and M. mamillare eggshells, respectively (Appendices 1 and 2), hence supporting a late Maastrichtian age.

Moratalla $(1993,1998)$ reported the oospecies Megaloolithus cf. mamillare and/or M. trempii in the localities of Orcau, Llabusta, Vicari, Compuertas, Fontllonga L and Suterranya, and Vianey-Liaud and López-Martínez (1997) identified the oospecies M. pseudomamillare and M. mamillare oospecies in the Suterranya-1 and Abella localities, respectively. Moratalla (1993) considered the eggshell localities of Orcau, Llabusta, Vicari, Compuertas and Suterranya to be Maastrichtian in age, whereas López-Martínez (2000) suggested a latest Campanian age for these as well as for the Suterranya-1 and Abella localities. In the case of the Vicari locality, Torices et al. (2012) indicated that the Vicari section encompasses the latest Campanian but also the early Maastrichtian. The authors also located the Vicari-4 locality, previously referred to the late Campanian but with no further information on the parataxonomic affinity of the eggshells (Torices Hernández, 2002; Torices et al. 2004; in press). Vicari-4 is geographically near to where Moratalla (1993) reported the Vicari locality, being located in the same ravine, and we consider that, if not the same site, they may both have a similar strati- 
graphic position and age. The present work maintains that M. pseudomamillare and $M$. trempii must be synonymised with $M$. baghensis and M. cf. mamillare with M. mamillare (Appendix 2); therefore, the occurrence of these oospecies in the abovementioned localities (Orcau, Llabusta, Vicari, Compuertas, Fontllonga L, Suterranya, Suterranya-1 and Abella) indicates a late Maastrichtian age. At the south-western margin of the Tremp Basin, we concur with Prieto-Márquez et al. (2013) that the Moror locality (the "Moró" locality reported by Brinkmann, 1984, 1988) is probably late Maastrichtian in age given the diachronous deposition of the "grey unit", which took place in a regressive context, and given that it becomes younger westward. Likewise, the Moror-1 locality would be of similar age. However, the latter locality yielded what were purported to be $M$. petralta eggshells and was dated as "early Rognacian" (Vianey-Liaud and López-Martínez, 1997). Pending the revision of this eggshell material, the age of this locality remains controversial. The Montrebei locality, which was originally regarded as early Maastrichtian (López-Martínez, 2000) and later as late Campanian-early Maastrichtian in age (Torices et al., in press), may also be of late Maastrichtian age. Unfortunately, there are no published data on the parataxonomic affinity of the dinosaurs eggshells recovered in this locality (López-Martínez, 2000), and the charophyte content (only Clavator brachycerus) has an ambiguous and wide stratigraphic range (Villalba-Breva and Martín-Closas, 2012).

In the Àger syncline, the Perauba-Figuerola locality represents the only south-Pyrenean locality with rhabdodontid remains (Llompart and Krauss, 1982) and yielded the oospecies Megaloolithus aureliensis (Appendix 1). Torices et al. (in press) reported dinosaur eggshells at the Figuerola-2 locality, but no further taxonomic assignation is provided by the authors. Figuerola- 2 was originally regarded as early Maastrichtian (Torices Hernández, 2002) and later as late Campanian (López-Martínez, 2003; Torices et al. 2004; in press). The two localities are geographically adjacent to one another (about $25 \mathrm{~m}$ apart) and stratigraphically almost equivalent. They are located in the lower part of the "Figuerola de Meià" unit, the regional equivalent of the "lower red unit" of the Tremp Formation. This continental unit contains a charophyte assemblage of Maastrichtian age (Septorella brachycera, $S$. ultima, Peckichara sertulata, and Maedleriella sp.; Fig. 2B) and overlies the La Maçana Fm., which is considered late Campanian in age on the basis of its charophyte assemblages (Villalba-Breva and Martín-Closas, 2012). Thus, the recent data on charophyte biostratigraphy indicate that both localities are most probably early Maastrichtian in age. The new age assignment is consistent with the magnetostratigraphical data of Galbrun et al. (1993), who correlated the base of the "Figuerola de Meià" unit with the C32r magnetochron (currently early Maastrichtian in age after Gradstein et al., 2012).

López-Martínez (2003) reported dinosaur eggshells from the Blancafort locality although she did not provide any further parataxonomic assignment. Recently, we have collected several eggshells, which have been attributed to Megaloolithus aureliensis (Appendices 1 and 2). The samples come from a lacustrine limestone on top of the La Maçana Fm. (late Campanian in age according to charophyte assemblages; Villalba-Breva and Martín-Closas, 2012). The occurrence of the oospecies M. aureliensis oospecies in Blancafort is consistent with this age assignment since this oospecies ranges temporally from the late Campanian to the early Maastrichtian (Garcia and Vianey-Liaud, 2001).

In the Coll de Nargó syncline most of the multiple eggbearing sites (Appendix 1) in the localities of Sallent, El Codó, Pinyes Est, Santa Eulàlia, La Teuleria, Cal Fontanet, and Els Encerris yielded a single oospecies, Megaloolithus siruguei (Appendix 2). The occurrence of this single oospecies for more than $100 \mathrm{~m}$ of stratigraphic section seems to indicate that most of these localities fall within the oozone 2 (in accordance with Sellés et al., 2013), which is mainly characteristic of the early Maastrichtian (Fig. 2A, B). In the same region the El Mirador locality yielded three megaloolithid oospecies (Cairanoolithus roussetensis, Megaloolithus siruguei and M. aureliensis; Sellés et al., 2013). This cooccurrence originally seemed to be characteristic of the late Campanian Oozone 1 of Garcia and Vianey-Liaud (2001) but with the new age calibration of Gradstein et al. (2012) the assemblage extends within the early Maastrichtian (C32n.1n). In the case of El Mirador locality, Sellés et al. (2013) assumed that it probably represents the last co-occurrence of these ootaxa in the Coll de Nargó area, and therefore the site may fall on the upper part of the C32n.1n and be early Maastrichtian in age. Finally, as noted by Vila et al. (2011) and Sellés et al. (2013), the egg-bearing sites of the upper part of the Coll Nargó and Vallcebre sections contain the oospecies M. siruguei right in contact with M. mamillare or M. baghensis (sites of Pinyes Est-5, Santa Eulàlia-3, El Codó-41, E-MUN06, J-BAR01; Appendix 1). This probably indicates that these sites fall around the $\mathrm{C} 31 \mathrm{r}-\mathrm{C} 31 \mathrm{n}$ reversal, which is late Maastrichtian in age according to the recent age calibrations of Gradstein et al. (2012).

Regarding the new eggshell-bearing localities reported in the present work (Appendices 1 and 2), some of them yielded M. mamillare eggshells (La Nou-1, Berguedà area, Barcelona; Tossal de Sant Romà d'Abella, and Costa de la Coma, Tremp Basin, Lleida) and M. baghensis eggshells (Sant Bartomeu, Barranc de la Boïga, Molí del Baró-1, Serrat del Rostiar-2, and Camí del Soldat, Tremp Basin, Lleida; L'Espinau, Àger Syncline, Lleida) and hence indicate a late Maastrichtian age. It is worth noting that some of these reports (localities of $\mathrm{La}$ Nou-1, Camí del Soldat and Molí del Baró-1) expand the temporal range of these two oospecies (M. mamillare and $M$. baghensis) into the $\mathrm{C} 29 \mathrm{r}$ magnetochron (Fig. 2A).

\subsection{Implications for dinosaur faunal turnover}

Le Loeuff et al. (1994) stated that a faunal replacement occurred around the early Maastrichtian-late Maastrichtian 


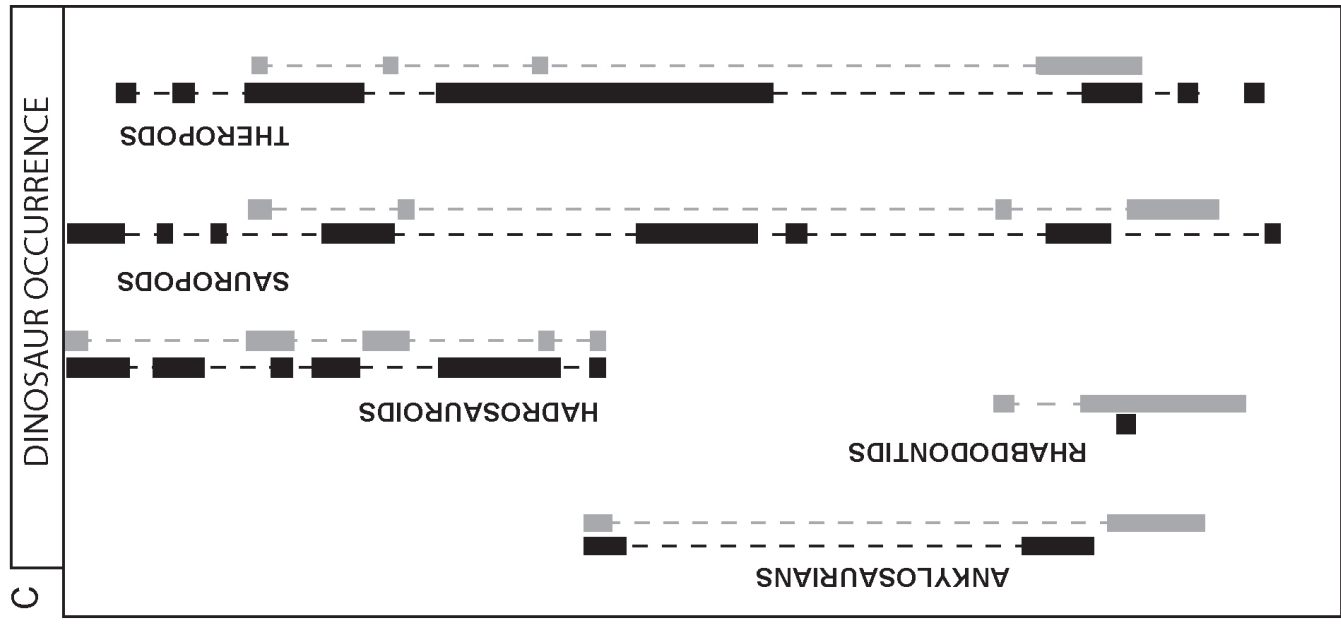

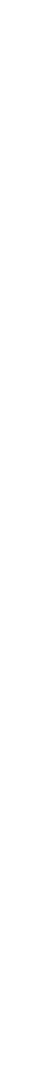
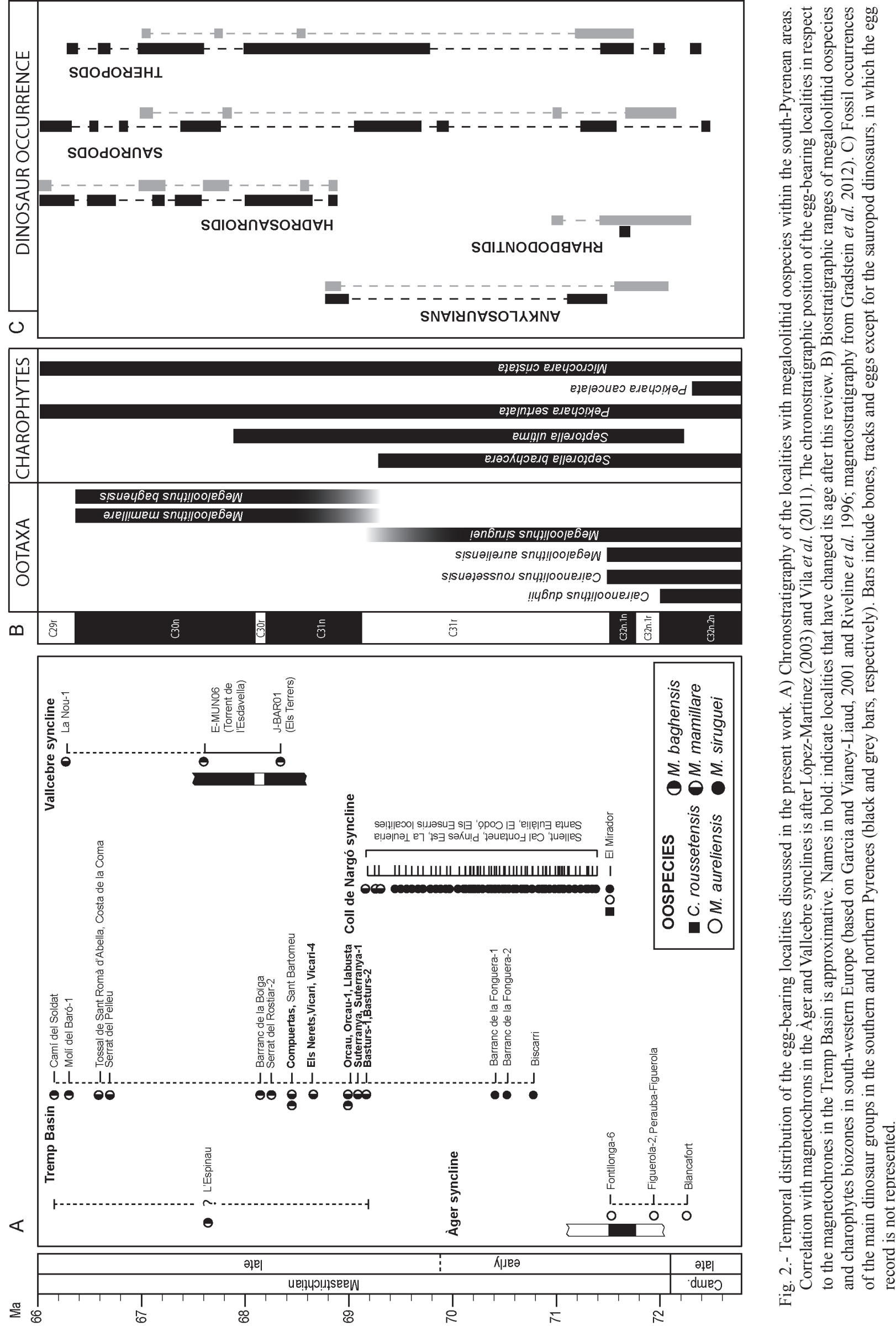
boundary in the so-called Ibero-Armorican Domain in southwestern Europe. During this turnover a late Maastrichtian assemblage dominated by hadrosauroids replaced an early Maastrichtian fauna dominated by titanosaurian sauropods. To understand how this purported turnover took place it is pivotal to establish the age of the dinosaur-bearing localities throughout the region. The new age assignments proposed for some south-Pyrenean localities have implications mainly for the temporal distribution of certain dinosaur taxa (ankylosaurians and theropods) in the latest Cretaceous and therefore for the turnover pattern of south-western Europe (Fig. 2). In the southern basins, for example, the localities of Fontllonga-6, Biscarri, Els Nerets and Suterranya-Mina de lignit yielded ankylosaurian remains (Santafé-Llopis et al., 1997; López-Martínez et al., 2000; López-Martínez, 2003; Escaso et al., 2010). The present revision indicates that at least two of these localities (Els Nerets and Suterranya-Mina de lignit) have a late Maastrichtian age, and this implies that the ankylosaurian dinosaurs persisted until the early late Maastrichtian (Fig. 2A). This assertion concurs with what has been reported in the northern Pyrenees (Fig. 2C), where ankylosaurian remains have been collected in deposits of late Maastrichtian age (Laurent et al., 2002). As a whole, the Pyrenean record seems to indicate that the clade did not go extinct at the early Maastrichtian-late Maastrichtian boundary but they lasted beyond it and coexisted for some time with hadrosauroid faunas.

In terms of theropod distribution and fossil abundance, the new age assignments proposed for some localities modify the recent theropod successions proposed by Torices et al. (in press) in the southern Pyrenees. For instance, the authors situated several of the localities with theropod teeth in the late Campanian. However, the Figuerola-2 locality is here considered to be early Maastrichtian in age, whereas the localities of Vicari-4, Suterranya-1 and probably Montrebei are late Maastrichtian in age. This implies that some of the theropod taxa reported in late Campanian localities are now restricted to the late Maastrichtian (Fig. 2A). This is the case for cf. Richardoestesia sp. and "Richardoestesia-like", which now seem to be restricted exclusively to the late Maastrichtian, at least in the southern Pyrenees. Moreover, with the new distribution the theropod record in the southern Pyrenees clearly varies through the latest Cretaceous in terms of the predominant type of evidence. That is, the oological record is more diverse than the bone record prior to the early Maastrichtianlate Maastrichtian boundary (Sellés et al., 2014). By contrast, the bone record (mainly teeth) is much more highly represented in deposits of late Maastrichtian age, being scarce in the late Campanian-early Maastrichtian interval. This pattern, which is probably influenced by sampling and other biases, comes to light clearly in Fig. 2C, where the theropod record is notably more concentrated in the late Maastrichtian.

Regarding sauropods, the late Maastrichtian age of some eggshell localities (e.g. Els Nerets, Basturs, Orcau, Suterran- ya-1) demonstrates that the egg record of this group is almost continuous and abundant throughout the entire Maastrichtian. This contradicts previous statements made by LópezMartínez (2003), who postulated a major abundance of egg localities in Upper Campanian and a decrease in Maastrichtian deposits. In the light of the new temporal distribution of the localities and the integration of new sites from other areas (e.g. the Coll de Nargó and Vallcebre synclines) the egg record of sauropod dinosaurs becomes notably scarce in Upper Campanian deposits but is well represented in the Maastrichtian

The new age assignments do not have significant implications for the temporal distribution of rhabdodontid and hadrosauroid dinosaurs, since the ornithopod-bearing localities discussed in the present work (Perauba-Figuerola, and Els Nerets and L'Espinau, respectively) fall within the time interval expected for each group in the region. The present study will hopefully lay the groundwork for future studies on dinosaur biostratigraphy not only in the southern Pyrenees but also in the whole Ibero-Armorican Domain.

\section{Conclusions}

The present study updates the nomenclature and age of several classic and new dinosaur fossil localities in the uppermost Cretaceous (Campanian-Maastrichtian) continental deposits of the southern Pyrenees. The age of about 30 localities has been re-evaluated by means of an analysis and review of new and previous parataxonomic assignations, with some material re-assigned to known megaloolithid oospecies $(M$. aureliensis, M. siruguei, M. mamillare, $M$. baghensis). The new age assignation includes classical dinosaur-bearing localities such as Basturs, Orcau-1, Els Nerets, Suterranya-1 and Figuerola-2, among others, which have significant implications for the faunal turnover proposed in south-western Europe. According to the new data, the ankylosaurians would have survived until the late Maastrichtian in the southern Pyrenees, as reported in the northern basins. The new age assessment suggests that in the southern Pyrenees the fossil record of theropods is scarce prior to the early Maastrichtian and that their taxonomic diversity (richness) is much higher in the late Maastrichtian. Interestingly, the sauropod egg record becomes continuous throughout the entire Maastrichtian but is scarce in the Upper Campanian.

\section{Acknowledgements}

This paper is a contribution to the projects CGL201130069-C02-01,02/BTE and CGL2010-16447, subsidized by the Ministerio de Economía y Competitividad of Spain. B. Vila acknowledges support from the Ministerio de Economía y Competitividad (Subprograma Juan de la Cierva MICINNJDC, 2011) and the Committee for Research and Exploration of the National Geographic Society. This paper is part 
of the unpublished $\mathrm{PhD}$ dissertation of AGS supported by a FI grant (2008FI-AGAUR). The Generalitat de Catalunya (Departament de Cultura) supported research and fieldwork. The authors thank Miguel Moreno-Azanza (Universidad de Zaragoza) and Géraldine Garcia (University of Poitiers) for their helpful reviews, Xabier Pereda-Suberbiola (Universidad del País Vasco/Euskal Herriko Unibertsitatea) for his corrections, Antoni Lacasa (Institut Estudis Ilerdencs), Lluís Ardèvol (Geoplay), Carme Llompart (Universitat Autònoma de Barcelona), Josep Marmi (Institut Català de Paleontologia), Rodrigo Gaete (Museu de la Conca Dellà), Josep Montané, and Ferran Albert for providing information on some localities, and the volunteers and field crew that assisted in sieving and collecting samples. We thank Patricia Pérez (Museo Nacional de Ciencias Naturales) and staff members of Serveis Científico-Tècnics (Campus UB). Rupert Glasgow reviewed the English.

\section{References}

Ardèvol, L., Casanovas, M.L., Santafé, J.V. (1995): Restos de dinosaurios del Maastrichtiense de la Conca de Tremp, Lleida, cuenca de antepaís pirenaica meridional). Resúmenes XI Jornadas de Paleontología, Tremp, Lleida, pp. 25-27.

Ardèvol, L., Vicens, E., Capdevila, J., López-Martínez, N. (1999): Field trip guide of the First international symposium on dinosaur eggs and babies. Unpublished report, Isona, Lleida (September $\left.26^{\text {th }}, 1999\right), 18 \mathrm{p}$.

Ardèvol, L., Klimowitz, J., Malagón, J., Nagtegaal, P.J.C. (2000): Depositional sequence response to foreland deformation in the Upper Cretaceous of the Southern Pyrenees, Spain. AAPG Bulletin 84, 566-587. doi: 10.1306/C9EBCE55-1735-11D7-8645000102C1865D.

Blain, H-A., Canudo, J.I., Cuenca-Bescós, G., López-Martínez, N. (2010): Amphibians and squamate reptiles from the latest Maastrichtian (Upper Cretaceous) of Blasi 2 (Huesca, Spain). Cretaceous Research 31, 433-446. doi: 10.1016/j.cretres.2010.06.001.

Bravo, A.M., Marugán-Lobón, J. (2013): Morphometric analysis of dinosaur eggshells: constraints of size on shape. Historical Biology 25, 697-704. doi: 10.1080/08912963.2012.744989.

Brinkmann, W. (1984): Erster Nachweis eines Hadrosauriers (Ornithischia) aus dem unteren Garumnium (Maastrichtium) des Beckens von Tremp (Provinz Lérida, Spanien). Paläontologische Zeitschrift 58, 295-305.

Brinkmann, W. (1988): Zur Fundgeschichte und Systematik der Ornithopoden (Ornithischia, Reptilia) aus der Ober-Kreide von Europa. Documenta Naturae 45, 1-157.

Buffetaut, E., Le Loeuff, J. (1991): Late Cretaceous dinosaur faunas of Europe: some correlation problems. Cretaceous Research 12, 159 176. doi: 10.1016/S0195-6671(05)80022-9.

Casanovas-Cladellas, M.L., Santafé-Llopis, J.V. (1993): Presencia de titanosáuridos (Dinosauria) en el Cretácico superior de Fontllonga (Lleida, España). Treballs del Museu de Geologia de Barcelona 3, 67-80.

Casanovas-Cladellas, M.L., Santafé-Llopis, J.V., Sanz, J.L., Buscalioni, A. (1985): Orthomerus (Hadrosaurinae, Ornithopoda) del Cretácico Superior del yacimiento de "Els Nerets" (Tremp, España). Paleontologia i Evolució 19, 155-162.

Casanovas, M.L., Santafé, J.V., Sanz, J.L., Buscalioni, A.D. (1987): Arcosaurios (Crocodilia, Dinosauria) del Cretácico superior de la Conca de Tremp (Lleida, España). Estudios Geológicos número extraordinario Galve-Tremp, 95-110.
Casanovas-Cladellas, M.L., Santafé-Llopis, J.V., Isidro-Llorens, A. (1993): Pararhabdodon isonense n. gen. n. sp. (Dinosauria). Estudio morfológico, radio-tomográfico y consideraciones biomecánicas. Paleontologia i Evolució 26-27, 121-131.

Casanovas, M.L., Pereda Suberbiola, X., Santafé, J.V., Weishampel, D.B. (1999): A primitive euhadrosaurian dinosaur from the uppermost Cretaceous of the Àger syncline (southern Pyrenees, Catalonia). Geologie en Mijnbouw 78, 345-356. doi: 10.1023/A:1003859501941.

Cruzado-Caballero, P., Pereda-Suberbiola, X., Ruiz-Omeñaca, J.I. (2010): Blasisaurus canudoi gen. et sp. nov., a new lambeosaurine dinosaur (Hadrosauridae) from the latest Cretaceous of Arén (Huesca, Spain). Canadian Journal of Earth Sciences 47, 1507-1517. doi: 10.1139/E10-081.

Dalla Vecchia, F.M., Riera, V., Oms, O., Dinarès-Turell, J., Gaete, R., Galobart, À. (2013): The last pterosaurs: First record from the uppermost Maastrichtian of the Tremp Syncline (Northern Spain). Acta Geologica Sinica 87, 1198-1227. doi: 10.1111/1755-6724.12146.

Dalla Vecchia, F. M., Gaete, R., Riera, V., Oms. O., Prieto-Márquez, A., Vila, B., G. Sellés, A., Galobart, À. (2014): The hadrosauroid record in the Maastrichtian of the eastern Tremp Syncline (northern Spain). In: D. Eberth, D.C. Evans (eds.), Hadrosaurs: Proceedings of the International Hadrosaur Symposium at the Royal Tyrrell Museum. Indiana University Press, Bloomington, 298-314.

Díaz-Molina, M. (1987): Sedimentación sintectónica asociada a una subida relativa del nivel del mar durante el Cretácico superior (Fm. Tremp, provincia de Lérida). Estudios Geológicos volumen extraordinario Galve-Tremp, 69-93.

Díaz-Molina, M., Kälin, O., Benito, M.I., López-Martínez, N., Vicens, E. (2007): Depositional setting and early diagenesis of the dinosaur eggshell-bearing Arén Fm at Bastús, Late Campanian, south-central Pyrenees. Sedimentary Geology 199, 205-221. doi: 10.1016/j.sedgeo.2007.02.002.

Escaso, F., Pérez-García, A., Ortega, F., Sanz, J.L. (2010): Ankylosaurian evidences from the Upper Cretaceous of South-Central Pyrenees (Lleida, Spain): a reappraisal. Abstracts $8^{\text {th }}$ Meeting of the European Association of Vertebrate Palaeontologists, Aix-en-Provence, pp. 33-35.

Feist, M., Colombo, F. (1983): La limite Crétacé-Tertiaire dans le nordest de l'Espagne, du point de vue des charophytes. Géologie Méditerranéenne 10, 303-326.

Galbrun, B., Feist, M., Colombo, F., Rocchia, R., Tambareau, Y. (1993): Magnetostratigraphy and biostratigraphy of Cretaceous-Tertiary continental deposits, Àger Basin, Province of Lérida, Spain. Palaeogeography, Palaeoclimatology, Palaeoecology 102, 41-52. doi: 10.1016/0031-0182(93)90004-3.

Garcia, G., Vianey-Liaud, M. (2001): Dinosaur eggshells as biochronological markers in Upper Cretaceous continental deposits. Palaeogeography, Palaeoclimatology, Palaeoecology 169, 153-164. doi: 10.1016/S0031-0182(01)00215-2.

Gradstein, F.M., Ogg, J.G., Schmitz, D.M., Ogg, G.M. (2012): The Geological Time Scale. Elsevier, Amsterdam, 1144 p.

Lapparent, A.F. (1958): Découverte d'un gisement à oeufs de dinosauriens dans le Crétacé supérieur du Bassin de Tremp (province de Lérida, Espagne). Comptes Rendus de l'Académie des Sciences Paris 247, 1879-1880.

Lapparent, A.F., Aguirre, E. (1956): Algunos yacimientos de Dinosaurios en el Cretácico superior de la Cuenca de Tremp. Estudios Geológicos 31-32, 377-382.

Laurent, Y., Bilotte, M., Le Loeuff, J. (2002): Late Maastrichtian continental vertebrates from southwestern France: correlation with marine fauna. Palaeogeography, Palaeoclimatology, Palaeoecology 187, 121-135. doi: 10.1016/S0031-0182(02)00512-6

Le Loeuff, J., Martínez, A. (1997): Afloramiento de icnitas de Titano- 
sauridae en la zona de Fumanya (Maastrichtiense, Pirineo oriental): estudio preliminar. Geogaceta, 21: 151-153.

Le Loeuff, J., Buffetaut, E., Martin, M. (1994): The last stages of dinosaur faunal history in Europe: A sucession of Maastrichtian dinosaur assemblages from the Corbières (southern France). Geological Magazine 31, 625-630.

Llompart, C., Krauss, S. (1982): Restos de moluscos y dinosaurios en formaciones estromatolíticas garumnienses al S del Montsec (Prov. de Lérida). Boletín Geológico y Minero 903, 371-378.

Llompart, C., Casanovas, M.L, Santafé, J.V. (1984): Un nuevo yacimiento de icnitas de Dinosaurios en las facies garumnienses de la Conca de Tremp (Lleida, España). Acta Geológica Hispánica 19, 143-147.

López-Martínez, N. (2000): Eggshell sites from the Cretaceous-Tertiary transition in South-Central Pyrenees (Spain). In: Bravo, A.M., Reyes, T. (eds.), First international symposium on dinosaur eggs and babies, Isona i Conda Dellá, Lleida, pp. 95-116.

López-Martínez, N. (2003): La extinción de los dinosaurios y su registro en los Pirineos. In: Colectivo Arqueológico-Paleontológico Salense (ed.), Actas II Jornadas Internacionales sobre Paleontología de Dinosaurios y su Entorno, Salas de los Infantes, Burgos, pp. 71LópezMartínez, N., Vicens E. (2012): A new peculiar dinosaur egg, Sankofa pyrenaica oogen. nov. oosp. nov. from the Upper Cretaceous coastal deposits of the Arén Formation, South-central Pyrenees, Lleida, Catalonia, Spain. Palaeontology 55, 325-339. doi:10.1111/j.14754983.2011.01114.x.

López-Martínez, N., Ardèvol, L., Arribas, M.E., Civis, J., González, J.A. (1998): The geological record in continental environments around the $\mathrm{K} / \mathrm{T}$ boundary (Tremp Formation, Spain). Bulletin de la Société Géologique de France 169, 11-20.

López-Martínez, N., Moratalla, J.J., Sanz, J.L. (2000): Dinosaurs nesting on tidal flats. Palaeogeography, Palaeoclimatology, Palaeoecology 160, 153-163. doi: 10.1016/S0031-0182(00)00063-8.

López-Martínez, N., Canudo, J.I., Ardèvol, L., Pereda Suberbiola, X., Orue-Etxebarria, X., Cuenca-Bescós, G., Ruiz-Omeñaca, J. I., Murelaga, X., Feist, M. (2001): New dinosaurs sites correlated with the Upper Maastrichtian pelagic deposits in the Spanish Pyrenees: implications for the dinosaur extinction pattern in Europe. Cretaceous Research 22, 41-61. doi: 10.1006/cres.2000.0236.

Marín, A., Bataller, J.R. (1929): Nuevos datos sobre el Cretácico superior de la Cuenca de Tremp (Lérida). Asociación Española para el Progreso de las Ciencias, Congreso de Barcelona 6, 25-28.

Marmi, J., Luján, A.H., Riera, V., Gaete, R., Oms, O., Galobart, À. (2012): The youngest species of Polysternon: A new bothremydid turtle from the uppermost Maastrichtian of the southern Pyrenees. Cretaceous Research 35, 133-142. doi: 10.1016/j.cretres.2011.12.004.

Médus, J., Colombo, F., Durand, J.P. (1992): Pollen and spore assemblages of the uppermost Cretaceous continental formations of southeastern France and north-eastern Spain. Cretaceous Research 13, 119-132. doi: 10.1016/0195-6671(92)90030-T.

Mikhailov, K. E. (1997): Fossil and recent eggshell in amniotic vertebrates: fine structure, comparative morphology and classification. Special Papers in Paleontology 56, 1-80.

Moratalla, J.J. (1993): Restos indirectos de dinosaurios del registro español: Paleoicnología de la Cuenca de Cameros (Jurásico superiorCretácico inferior) y paleoología del Cretácico superior. Unpublished Doctoral Thesis, Universidad Autónoma de Madrid, Madrid, 286 p.

Moratalla, J.J. (1998): Spanish dinosaur eggs. In: A.M.G. de Carvalho, A.M. Andrade, V.F. dos Santos, J. Cascalho, R. Taborda, (eds.), I Encontro Internacional sobre Paleobiologia dos Dinossáurios. Museu Nacional de História Natural, Lisboa, pp. 26-35.

Oms, O., Dinarès-Turell, J., Vicens, E., Estrada, R., Vila, B., Galobart, À., Bravo, A.M. (2007): Integrated stratigraphy from the Vallcebre Basin (southeastern Pyrenees, Spain): new insights on the continental Cretaceous-Tertiary transition in southwest Europe. Palaeogeogra- phy, Palaeoclimatology, Palaeoecology 255, 35-47. doi: 10.1016/j. palaeo.2007.02.039.

Pereda-Suberbiola, X., Ruiz-Omeñaca, J.I. (2012): Discovery and study of dinosaurs from Spain: The contribution of Albert F. de Lapparent. Comptes Rendus Palevol 11, 315-322. doi: 10.1016/j.palaeo.2007.02.039

Pereda-Suberbiola, X., Ruiz-Omeñaca, J.I., Company, J. (2003): Los dinosaurios hadrosaurios del registro ibérico. Descripción de nuevo material del Cretácico superior de Laño (Condado de Treviño). In: Pérez-Lorente, F. (ed.), Dinosaurios y otros reptiles mesozoicos en España, Instituto de Estudios Riojanos (IER), Logroño. Ciencias de la Tierra 26, pp. 375-388.

Pereda-Suberbiola, X., Canudo, J.I., Cruzado-Caballero, P., Barco, J.L., López-Martínez, N., Oms, O., Ruiz-Omeñaca, J.I. (2009): The last hadrosaurid dinosaurs of Europe: a new lambeosaurine from the uppermost Cretaceous of Arén (Huesca, Spain). Comptes Rendus Palevol 8, 559-572. doi: 10.1016/j.crpv.2009.05.002.

Prieto-Márquez, A., Gaete, R., Galobart, À., Ardevol, L. (2000): A Richardoestesia-like theropod tooth from the Late Cretaceous foredeep, South-central Pyrenees, Spain. Eclogae Geologica Helvetica 93, 497-501.

Prieto-Márquez, A., Dalla Vecchia, F.M., Gaete, R., Galobart, À. (2013): Diversity, relationships, and biogeography of the lambeosaurine dinosaurs from the European archipelago, with description of the new aralosaurin Canardia garonnensis. PLoS ONE 8, e69835. doi: 10.1371. pone.0069835.

Puértolas, E., Canudo, J.I., Cruzado-Caballero, P. (2011): A new crocodylian from the late Maastrichtian of Spain: Implications for the initial radiation of crocodyloids. PLOS ONE 6, e20011. doi: 10.1371/ journal.pone.0020011.

Puértolas-Pascual, E., Canudo, J. I., Moreno-Azanza, M. (2014): The eusuchian crocodylomorph Allodaposuchus subjuniperus sp. nov., a new species from the latest Cretaceous (upper Maastrichtian) of Spain. Historical Biology 26, 91-109. doi: 10.1080/08912963.2012.763034.

Riera, V., Oms, O., Gaete., R., Galobart, À. (2009): The end-Cretaceous dinosaur succession in Europe: The Tremp Basin record (Spain). Palaeogeography, Palaeoclimatology, Palaeoecology 283, 160-171. doi: 10.1016/j.palaeo.2009.09.018.

Riveline, J., Berger, J-P., Feist, M., Martín-Closas, C., Schudack, M., Soulié-Märsche, I. (1996): European Mesozoic-Cenozoic charophyte biozonation. Bulletin de la Société Géologique de la France 167, 454-468.

Rosell, J., Linares, R., Llompart, C. (2001): El "Garumniense” prepirenaico. Revista de la Sociedad Geológica de España 14, 47-56.

Santafé-Llopis, J.V., Casanovas-Cladellas, L., Llompart, C. (1997): Els dinosaures i el seu entorn geològic. Diputació de Lleida, Lleida, 69 p.

Sellés, A. G., Bravo, A.M., Delclòs, X., Colombo, F., Martí, X., Ortega-Blanco, J., Parellada, C., Galobart, À. (2013): Dinosaur eggs in the Upper Cretaceous of the Coll de Nargó area, Lleida Province, south-central Pyrenees, Spain: Oodiversity, biostratigraphy and their implications. Cretaceous Research 40, 10-20. doi: 10.1016/j.cretres.2012.05.004

Sellés, A. G., Vila, B., Galobart, À. (2014): Diversity of theropod ootaxa and its implications for the latest Cretaceous dinosaur turnover in southwestern Europe. Cretaceous Research 49, 45-54. doi: 10.1016/j. cretres.2014.02.004.

Suñer, M., Poza, B., Vila, B., Santos-Cubedo. A. (2008): Síntesis del registro fósil de dinosaurios en el Este de la Península Ibérica. Publicaciones del Seminario de Paleontología de Zaragoza 8, 397-420.

Torices Hernández, A. (2002): Los dinosaurios terópodos del Cretácico Superior de la Cuenca de Tremp (Pirineos Sur-Centrales, Lleida). Coloquios de Paleontología 53, 139-146.

Torices, A., Ruiz Omeñaca, J.I., Canudo, J.I., López-Martínez, N. (2004): Nuevos datos sobre los dinosaurios terópodos (Saurischia: 
Theropoda) del Cretácico superior de los Pirineos Sur-Centrales (Huesca y Lleida). Geo-Temas 6, 71-74.

Torices, A., Fernández-Marrón, M.T., Fonollá, F., López-Martínez, N. (2012): Palynological characterization of a transgressive episode in transitional deposits in the Cretaceous Aren and Tremp formations (south-central Pyrenees, Spain). Neues Jahrbuch für Geologie und Paläontologie Abhandlungen 266, 159-172. doi: 10.1127/00777749/2012/0291.

Torices, A., Currie, P.J., Canudo, J.I., Pereda-Suberbiola, X. (in press): Theropod dinosaurs from the Upper Cretaceous of the South Pyrenees Basin of Spain. Acta Palaeontologica Polonica. doi: 10.4202/ app.2012.0121.

Val, S., García, R., López, D. (2014): Preliminary results on the chemical preparation of dinosaur eggshells. Journal of Paleontological Techniques 13, 29-37.

Vianey-Liaud, M., López-Martínez, N. (1997): Late Cretaceous dinosaur eggshells from the Tremp Basin (Southern Pyrenees, Lleida, Spain). Journal of Paleontology 71, 1157-1171.

Vianey-Liaud, M., Khosla, A., Garcia, G. (2003): Relationships between European and Indian dinosaur eggs and eggshells of the oofamily megaloolithidae. Journal of Vertebrate Paleontology 23, 575-585. doi: http://dx.doi.org/10.1671/0272-4634(2003)023[0575:RBEAID] 2.0.CO;2.

Vicens, E. , Ardèvol, L., López-Martínez, N., Arribas, M.E. (2004): Rudist biostratigraphy in the Campanian-Maastrichtian of the southcentral Pyrenees, Spain. Courier Forschungsinstitut Senckenberg
$247,113-127$

Vila, B., Gaete, R., Galobart, À., Oms, O., Peralba, J., Escuer, J. (2006): Nuevos hallazgos de dinosaurios y otros tetrápodos continentales en los Pirineos sur-centrales y orientales: resultados preliminares. In: Colectivo Arqueológico-Paleontológico Salense (ed.), Actas III Jornadas Internacionales sobre Paleontología de Dinosaurios y su Entorno, Salas de los Infantes, Burgos, pp. 365-378.

Vila, B., Riera, V., Bravo, A.M., Oms, O., Vicens, E., Estrada, R., Galobart, À. (2011): The chronology of dinosaur oospecies in southern Europe: refinements from the Maastrichtian succession of the Eastern Pyrenees. Cretaceous Research 32, 378-386. doi: 10.1016/j.cretres.2011.01.009.

Vila, B., Galobart, À., Canudo, J.I., Le Loeuff, J., Dinarès-Turell, J., Riera, V., Oms, O., Tortosa, T., Gaete, R. (2012): The diversity of sauropod dinosaurs and their first taxonomic succession from the latest Cretaceous of southwestern Europe: Clues to demise and extinction. Palaeogeography, Palaeoclimatology, Palaeoecology 350-352, 19-38. doi: 10.1016/j.palaeo.2012.06.008.

Vila, B., Oms, O., Fondevilla, V., Gaete, R., Galobart, À., Riera, V., Canudo, J.I. (2013): The latest succession of dinosaur tracksites in Europe: hadrosaur ichnology, track production and paleoenvironments. PLoS ONE 8, e72579. doi: 10.1371/journal.pone.0072579.

Villalba-Breva, S., Martín-Closas, C. (2012): Upper Cretaceous paleogeography of the Central Southern Pyrenean Basins (Catalonia, Spain) from microfacies analysis and charophyte biostratigraphy. Facies 59, 319-345. doi: 10.1007/s10347-012-0317-1

\section{Appendix 1.- Listed samples and localities with megaloolithid oospecies discussed in the present work.}

\begin{tabular}{|c|c|c|c|c|c|}
\hline Locality & $\begin{array}{c}\text { Egg-bearing level } \\
\text { (site) }\end{array}$ & $\begin{array}{c}\text { Source } \\
\text { material }\end{array}$ & $\begin{array}{c}\text { Number of } \\
\text { samples }\end{array}$ & $\begin{array}{c}\text { Eggshell thickness } \\
(\mathrm{mm})\end{array}$ & Oospecies \\
\hline \multirow{2}{*}{ Barranc de La Fonguera } & Barranc de La Fonguera-1 & Egg debris & 7 & $2.67-2.73$ & Megaloolithus siruguei \\
\hline & Barranc de La Fonguera-2 & Egg debris & 12 & $2.17-2.39$ & Megaloolithus siruguei \\
\hline Barranc de la Boïga & - & Eggshells & 95 & $1.33-1.53$ & Megaloolithus baghensis \\
\hline Orcau-1 & - & Eggshells & 38 & $1.50-1.54$ & Megaloolithus baghensis \\
\hline Els Nerets & - & Eggshells & 51 & $1.64-1.77$ & Megaloolithus mamillare \\
\hline Suterranya-1 & - & Eggs & 25 & $1.76-1.78$ & Megaloolithus baghensis \\
\hline Abella & - & Eggs & 5 & 1.85 & Megaloolithus mamillare \\
\hline Tossal de Sant Romà d'Abella & - & Eggs & 84 & $1.54-1.62$ & Megaloolithus mamillare \\
\hline Costa de la Coma & - & Eggs & 110 & $1.56-1.64$ & Megaloolithus mamillare \\
\hline Sant Bartomeu & - & Egg & 6 & $1.47-1.88$ & Megaloolithus baghensis \\
\hline Molí del Baró-1 & - & Eggshells & 50 & $1.87-1.93$ & Megaloolithus baghensis \\
\hline Serrat del Rostiar-2 & - & Eggshells & 1 & 1.82 & Megaloolithus baghensis \\
\hline Camí del Soldat & - & Eggshells & 50 & $1.12-1.32$ & Megaloolithus baghensis \\
\hline Els Terrers & J-BAR01 & Egg & 4 & $0.7-0.9$ & Megaloolithus baghensis \\
\hline Torrent de l'Esdavella & E-MUN06 & Eggshells & 1 & 0.75 & Megaloolithus baghensis \\
\hline La Nou-1 & - & Eggshells & 119 & $1.51-1.59$ & Megaloolithus mamillare \\
\hline L’Espinau & - & Eggshells & 8 & $1.25-1.85$ & Megaloolithus baghensis \\
\hline Perauba-Figuerola & - & Eggshells & 1 & 1.57 & Megaloolithus aureliensis \\
\hline Blancafort & - & Eggshells & 17 & $1.50-1.61$ & Megaloolithus aureliensis \\
\hline \multirow{7}{*}{ Sallent } & Sallent-1 & Eggs & 6 & $2.78-2.95$ & Megaloolithus siruguei \\
\hline & Sallent-2 & Eggs & 12 & $2.93-3.22$ & Megaloolithus siruguei \\
\hline & Sallent-3 & Egg debris & 3 & $2.92-2.95$ & Megaloolithus siruguei \\
\hline & Sallent-4 & Eggs & 4 & $2.80-3.10$ & Megaloolithus siruguei \\
\hline & Sallent-5 & Eggs & 6 & $2.11-2.34$ & Megaloolithus siruguei \\
\hline & Sallent-6 & Eggs & 3 & $2.79-2.93$ & Megaloolithus siruguei \\
\hline & Sallent-7 & Eggs & 13 & $2.57-2.65$ & Megaloolithus siruguei \\
\hline \multirow{4}{*}{ Cal Fontanet } & Cal Fontanet-1 & Eggs & 29 & $3.14-3.66$ & Megaloolithus siruguei \\
\hline & Cal Fontanet-2 & Eggs & 10 & $3.33-3.61$ & Megaloolithus siruguei \\
\hline & Cal Fontanet-3 & Eggs & 9 & $3.34-3.76$ & Megaloolithus siruguei \\
\hline & Cal Fontanet-4 & Eggs & 26 & $3.45-3.65$ & Megaloolithus siruguei \\
\hline \multirow{5}{*}{ Pinyes Est } & Pinyes Est-1 & Eggs & 77 & $2.51-2.59$ & Megaloolithus siruguei \\
\hline & Pinyes Est-2 & Eggs & 11 & $2.73-2.87$ & Megaloolithus siruguei \\
\hline & Pinyes Est-3 & Egg debris & 20 & $2.37-2.79$ & Megaloolithus siruguei \\
\hline & Pinyes Est-4 & Eggs & 12 & $2.54-2.72$ & Megaloolithus siruguei \\
\hline & Pinyes Est-5 & Eggs & 23 & $1.98-2.07$ & Megaloolithus mamillare \\
\hline
\end{tabular}


Appendix 1.- (continuation).

\begin{tabular}{|c|c|c|c|c|c|}
\hline \multirow{4}{*}{ Santa Eulàlia } & Santa Eulàlia-1 & Eggs & 15 & $2.53-2.92$ & Megaloolithus siruguei \\
\hline & Santa Eulàlia-2 & Eggs & 28 & $2.48-2.73$ & Megaloolithus siruguei \\
\hline & Santa Eulàlia-3 & Eggs & 6 & $1.97-2.19$ & Megaloolithus mamillare \\
\hline & Santa Eulàlia-4 & Egg debris & 4 & $2.63-2.77$ & Megaloolithus siruguei \\
\hline \multirow{10}{*}{ La Teuleria } & La Teuleria-1 & Eggs & 50 & $2.29-2.49$ & Megaloolithus siruguei \\
\hline & La Teuleria-2 & Eggs & 93 & $3.08-3.16$ & Megaloolithus siruguei \\
\hline & La Teuleria-3 & Eggs & 5 & $2.57-2.66$ & Megaloolithus siruguei \\
\hline & La Teuleria-4 & Eggs & 152 & $2.86-3.01$ & Megaloolithus siruguei \\
\hline & La Teuleria-5 & Eggs & 7 & $2.93-3.22$ & Megaloolithus siruguei \\
\hline & La Teuleria-6 & Eggs & 92 & $2.48-2.73$ & Megaloolithus siruguei \\
\hline & La Teuleria-7 & Eggs & 117 & $2.31-2.45$ & Megaloolithus siruguei \\
\hline & La Teuleria-8 & Eggs & 96 & $2.78-2.95$ & Megaloolithus siruguei \\
\hline & La Teuleria-9 & Eggs & 78 & $2.52-2.65$ & Megaloolithus siruguei \\
\hline & La Teuleria-10 & Eggs & 11 & $2.71-2.75$ & Megaloolithus siruguei \\
\hline \multirow{12}{*}{ Els Enserris } & Els Enserris-1 & Eggs & 9 & $2.68-2.82$ & Megaloolithus siruguei \\
\hline & Els Enserris-2 & Eggs & 6 & $2.88-2.93$ & Megaloolithus siruguei \\
\hline & Els Enserris-3 & Eggs & 30 & $2.66-3.04$ & Megaloolithus siruguei \\
\hline & Els Enserris-4 & Eggs & 15 & $2.76-2.94$ & Megaloolithus siruguei \\
\hline & Els Enserris-5 & Eggs & 13 & $2.85-2.87$ & Megaloolithus siruguei \\
\hline & Els Enserris-5 & Eggs & 15 & $3.21-3.33$ & Megaloolithus siruguei \\
\hline & Els Enserris-6 & Eggs & 13 & 3.04-3.09 & Megaloolithus siruguei \\
\hline & Els Enserris-7 & Eggs & 10 & $2.11-2.81$ & Megaloolithus siruguei \\
\hline & Els Enserris-8 & Eggs & 20 & $2.43-2.72$ & Megaloolithus siruguei \\
\hline & Els Enserris-9 & Eggs & 7 & $2.83-2.99$ & Megaloolithus siruguei \\
\hline & Els Enserris-10 & Eggs & 67 & $2.63-2.67$ & Megaloolithus siruguei \\
\hline & Els Enserris-11 & Eggs & 32 & $2.78-2.92$ & Megaloolithus siruguei \\
\hline \multirow{41}{*}{ El Codó } & El Codó-1 & Eggs & 33 & $2.53-2.56$ & Megaloolithus siruguei \\
\hline & El Codó-2 & Eggs & 34 & $2.40-2.57$ & Megaloolithus siruguei \\
\hline & El Codó-3 & Eggs & 11 & $2.57-2.66$ & Megaloolithus siruguei \\
\hline & El Codó-4 & Eggs & 5 & $2.58-2.62$ & Megaloolithus siruguei \\
\hline & El Codó-5 & Eggs & 3 & $2.22-2.31$ & Megaloolithus siruguei \\
\hline & El Codó-6 & Eggs & 3 & $2.73-2.84$ & Megaloolithus siruguei \\
\hline & El Codó-7 & Eggs & 29 & $2.82-2.88$ & Megaloolithus siruguei \\
\hline & El Codó-8 & Eggs & 38 & $2.62-2.92$ & Megaloolithus siruguei \\
\hline & El Codó-9 & Eggs & 18 & $2.72-2.84$ & Megaloolithus siruguei \\
\hline & El Codó-10 & Eggs & 3 & $3.08-3.26$ & Megaloolithus siruguei \\
\hline & El Codó-11 & Eggs & 5 & $2.38-2.52$ & Megaloolithus siruguei \\
\hline & El Codó-12 & Eggs & 12 & $2.38-2.59$ & Megaloolithus siruguei \\
\hline & El Codó-13 & Eggs & 42 & $2.29-2.49$ & Megaloolithus siruguei \\
\hline & El Codó-14 & Eggs & 15 & $2.24-2.48$ & Megaloolithus siruguei \\
\hline & El Codó-15 & Eggs & 2 & $3.07-3.13$ & Megaloolithus siruguei \\
\hline & El Codó-16 & Eggs & 47 & $2.84-2.99$ & Megaloolithus siruguei \\
\hline & El Codó-17 & Eggs & 8 & $2.64-2.72$ & Megaloolithus siruguei \\
\hline & El Codó-18 & Eggs & 16 & $2.53-2.67$ & Megaloolithus siruguei \\
\hline & El Codó-19 & Eggs & 26 & $2.77-2.86$ & Megaloolithus siruguei \\
\hline & El Codó-20 & Eggs & 12 & $2.51-2.63$ & Megaloolithus siruguei \\
\hline & El Codó-21 & Eggs & 33 & $3.18-3.33$ & Megaloolithus siruguei \\
\hline & El Codó-22 & Eggs & 28 & $2.70-2.75$ & Megaloolithus siruguei \\
\hline & El Codó-23 & Eggs & 10 & $2.16-2.35$ & Megaloolithus siruguei \\
\hline & El Codó-24 & Eggs & 10 & $2.28-2.42$ & Megaloolithus siruguei \\
\hline & El Codó-25 & Eggs & 15 & $2.84-2.87$ & Megaloolithus siruguei \\
\hline & El Codó-26 & Eggs & 23 & $2.20-2.32$ & Megaloolithus siruguei \\
\hline & El Codó-27 & Eggs & 15 & $2.86-2.92$ & Megaloolithus siruguei \\
\hline & El Codó-28 & Eggs & 45 & $2.77-2.97$ & Megaloolithus siruguei \\
\hline & El Codó-29 & Eggs & 15 & $2.76-2.99$ & Megaloolithus siruguei \\
\hline & El Codó-30 & Eggs & 15 & $2.31-2.45$ & Megaloolithus siruguei \\
\hline & El Codó-31 & Eggs & 10 & $2.71-2.79$ & Megaloolithus siruguei \\
\hline & El Codó-32 & Eggs & 8 & $3.08-3.20$ & Megaloolithus siruguei \\
\hline & El Codó-33 & Eggs & 18 & $2.54-2.76$ & Megaloolithus siruguei \\
\hline & El Codó-34 & Eggs & 20 & $2.44-2.57$ & Megaloolithus siruguei \\
\hline & El Codó-35 & Eggs & 35 & $2.47-2.56$ & Megaloolithus siruguei \\
\hline & El Codó-36 & Eggs & 24 & $3.15-3.19$ & Megaloolithus siruguei \\
\hline & El Codó-37 & Eggs & 7 & $2.29-2.33$ & Megaloolithus siruguei \\
\hline & El Codó-38 & Eggs & 35 & $2.78-2.83$ & Megaloolithus siruguei \\
\hline & El Codó-39 & Eggs & 53 & $2.28-2.34$ & Megaloolithus siruguei \\
\hline & El Codó-40 & Eggs & 10 & $2.17-2.25$ & Megaloolithus siruguei \\
\hline & El Codó-41 & Eggs & 8 & $1.98-2.07$ & Megaloolithus mamillare \\
\hline
\end{tabular}




\section{Appendix 2.- Systematic palaeontology}

Basic organizational group: Dinosauroid

Oofamily: Megaloolithidae Zhao, 1979

Oogenus: Megaloolithus Vianey-Liaud, Mallan, Buscail, and Montgelard, 1994

Megaloolithus aureliensis Vianey-Liaud, Mallan, Buscail, and Montgelard, 1994

Diagnosis according to Garcia and Vianey-Liaud (2001): Megaloolithus with short fan-shaped units; arched growth lines can be horizontal in the small area with flat outer surface; thickness ranges from 0.75 to $1.52 \mathrm{~mm}$; average node diameter about $0.5 \mathrm{~mm}$; pore diameters between 10 and $50 \mu \mathrm{m}$; spherical eggs (until 20-22 cm).

Localities, stratigraphic range, and age: This Megaloolithus ooespecies is represented by scattered eggshells at the Blancafort and Perauba-Figuerola localities. The former locality falls on top of the La Maçana unit, the regional equivalent of the "grey unit" of the Tremp Formation, late Campanian (Villalba-Breva and MartínClosas, 2012). The Perauba-Figuerola locality locates at the lower part of the "Figuerola de Meià" unit, the regional equivalent of the "lower red unit" of the Tremp Formation, early Maastrichtian (Villalba-Breva and Martín-Closas, 2012).

Material: see Appendix 1.

Description: The outer surface of the eggshell is covered with scattered rounded nodes $(0.5 \mathrm{~mm}$ in diameter $)$, sometimes coalescent, with flat areas between them (Fig. 1A). Circular-shaped pore apertures (80-120 $\mu \mathrm{m}$ in diameter) are located at the base of nodes, and less frequently in the middle of flatted areas. Eggshell ranges from $0.8 \mathrm{~mm}$ to $1.2 \mathrm{~mm}$ in thickness. In radial view, short fanshaped shell units (H/W ratio of 1.8) are interlocked with adjacent ones (Fig. 1B). Growth lines are mainly arched at the base of those shell units, whereas they are undulating when crossing fused units. Some tubocanaliculate pore channels have been also observed in radial section, which are $95-120 \mu \mathrm{m}$ in width.

Comparisons and Discussion: Coalescent-nodular ornamentation like that of eggshells from the Blancafort and Perauba-Figuerola localities has been described in four megaloolithid oospecies: $M$. baghensis, Pseudomegaloolithus atlasis, Patagoolithus salitraensis and M. aureliensis (Vianey-Liaud et al., 2003; Vianey-Liaud and Garcia, 2003). All these oospecies exhibit similar structural features, such as shell-thickness, shape of shell units, and node and pore dimension; being the high/width ratio ( $\mathrm{H} / \mathrm{W}$ ratio) of the shell units the most notable differences between them. This value is about 2.33 in M. baghensis (Khosla and Sahni, 1995), less than 3 in $P$. atlasis (Vianey-Liaud and Garcia, 2003), 2.28 in P. salitralensis (Simón, 2006) and 1.75 in M. aureliensis (Sellés et al., 2013). Given that $\mathrm{H} / \mathrm{W}$ ratio established for the studied material is 1.8 , this value is more similar to that of $M$. aureliensis than any other oospecies. Although eggshell thickness can be highly variable within a certain oospecies, and that eggshell-thickness-range may overlap between several oospecies, it is worthy comment that the thickness of the oological material from the studied localities is more similar to $M$. aureliensis ( $0.9 \mathrm{~mm}$ and $0.98 \mathrm{~mm}$, respectively) than any other of the previously referred oospecies $(0.7 \mathrm{~mm}$-thick in $P$. atlasis, 1.5 mm-thick in M. baghensis, and $1.4 \mathrm{~mm}$-thick in $P$. salitralensis). Although the size of pore apertures of the studied material is somewhat larger than that reported by Garcia and Vianey-Liaud (2001), Sellés et al. (2013) described some specimens of $M$. aureliensis from Coll de Nargó syncline with similar values of pore apertures size than those of the present work. Therefore, eggshells from the
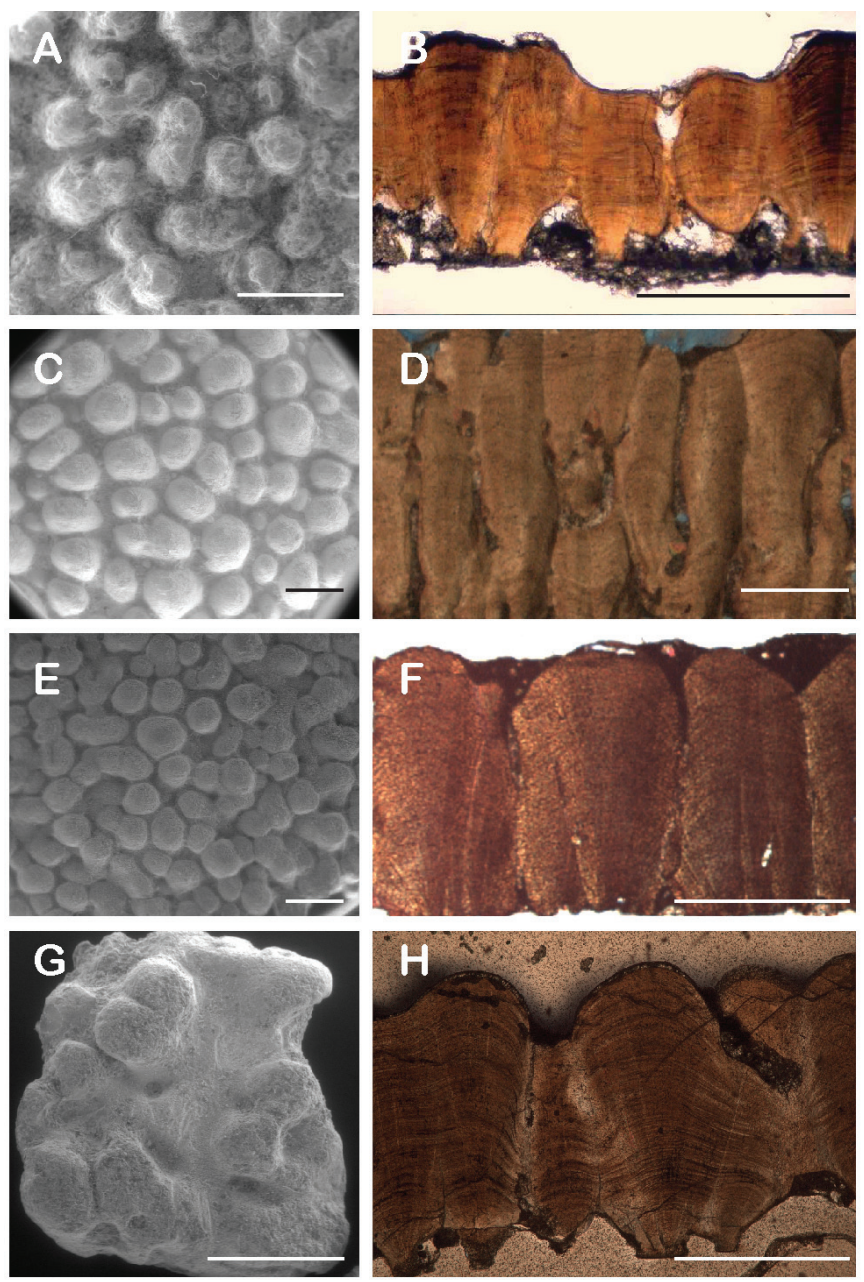

Appendix 2 Fig. 1 (suppl.) - Megaloolithid oospecies from the studied localities (southern Pyrenees). A, B) Megaloolithus aureliensis (IPS-58959) from the Blancafort locality, outer surface and radial section, respectively; C, D) Megaloolithus siruguei from the Pinyes Est-1 (IPS-82192) site, outer surface and radial section, respectively; E, F) Megaloolihus mamillare from the Tossal de Sant Romà d'Abella (IPS-58963) and Costa de la Coma (IPS-58964) localities, outer surface and radial section, respectively; G, H) Megaloolithus baghensis from the Barranc de la Boïga (IPS-58960) and Orcau-1 (IPS-9133) localities, outer surface and radial section, respectively. Scale bar: $1 \mathrm{~mm}$.

Blancafort and Perauba-Figuerola localities are attributed to the oospecies M. aureliensis.

Megaloolithus siruguei Vianey-Liaud, Mallan, Buscail, and Montgelard, 1994

Diagnosis: According to Vianey-Liaud et al (1994) and after Elez and López-Martínez (2000), and Vianey-Liaud and Zelenitsky (2003), Megaloolithus with shell units taller than in M. mammilare; thickness range 2.65 to $2.70 \mathrm{~mm}$; pore diameter range 50 to $80 \mu \mathrm{m}$; reticulate pore system.

Localities, stratigraphic range, and age: This Megaloolithus ooespecies is represented by eggs and/or scattered eggshells at the sites of Barranc de la Fonguera-1, and -2, Sallent-1 to -7, Cal Fontanet-1 to -4, Pinyes Est-1 to -4, La Teuleria-1 to -10, Santa Eulàlia-1, -2 , and -4 , El Codó-1 to -40, and Els Enserris-1 to -11. They all fall in the "lower red unit" of the Tremp Formation. Early Maastrichtian - ?early late Maastrichtian.

Material: see appendix 1 . 
Description: Relatively thick eggshells $(1.75 \mathrm{~mm}$ to $3.6 \mathrm{~mm})$, fully covered by well-delimited rounded nodes $(0.51-1.23 \mathrm{~mm}$ in diameter, Fig. 1C). Circular to sub-circular pore apertures (130 $\mu \mathrm{m}$-width), which are located near the base of the nodes. In radial section, the edge of the elongate fan-shaped shell units $(\mathrm{H} / \mathrm{W}$ ratio $=$ 4) can be easily traceable throughout whole eggshell. Nevertheless, some of them are partially interlocked with their neighbouring ones (Fig. 1D). Growth lines are clearly arched from the base to the top of the shell units. The respiratory channel system is composed of vertical funnel-shaped channels interconnected by transversal channels, altogether forming a reticulate network of channels.

Comparisons and Discussion: Only two oospecies of Megaloolithus exhibit a clear reticulate channel system: M. siruguei and M. microtuberculata. The surface of M. microtuberculata is covered of pronounced small nodes, sometimes with irregular shape (Garcia and Vianey-Liaud, 2001), while M. siruguei is covered of large rounded nodes, as in eggshells described above. In fact, the ornamental pattern is the only difference observed between these oospecies. Given that all the oological remains examined here exhibit large rounded nodes in their outer surface and reticulate pore system, they are classified as Megaloolithus siruguei.

Megaloolithus mamillare Vianey-Liaud, Mallan, Buscail, and Montgelard, 1994

Diagnosis according to Vianey-Liaud et al. (1994): Megaloolithus with short fan-shaped units; thickness in the main part of the eggshells from 1.2 to $2.1 \mathrm{~mm}$; average node diameter about $1 \mathrm{~mm}$; pore diameters range from 75 to $120 \mathrm{pm}$.

Synonymy: Megaloolithus cf. mamillare from the Compuertas locality of Moratalla (1993)

Localities, stratigraphic range, and age: This Megaloolithus ooespecies is represented by eggs and scattered eggshells at the Basturs-1, Basturs-2, Abella and Sant Bartomeu localities, on top of the Arén Sandstone Formation; eggshell fragments in the Els Nerets and Compuertas localities, in the "grey unit" of the Tremp Formation; and eggs and/or eggshell fragments from the Santa Eulàlia-3, El Codó-41, Pinyes Est-5, Tossal de Sant Romà d'Abella, Costa de la Coma, and La Nou-1 localities, in the upper part of the "lower red unit" of the Tremp Formation. Late Maastrichtian.

Material: see Appendix 1.

Description: Some nearly complete sub-spherical eggs (19-20 cm in diameter) have been discovered in Tossal de Sant Romà d'Abella locality. Eggshell ranges from $1.39 \mathrm{~mm}$ to $2.3 \mathrm{~mm}$ in thickness (average of $1.9 \mathrm{~mm}$ ) with the outer surface covered of small rounded nodes $(0.73 \mathrm{~mm}$ in diameter). Sometimes, nodes are coalescenced between two or five nodes, forming short and irregular chains (Fig. 1E). Circular-shaped pore apertures $(90-110 \mu \mathrm{m}$ in diameter $)$ are located between ornamental nodes. In radial thin section, fanshaped shell units (H/W ratio of 2) are clearly traceable; showing well curved growth lines from the base to the top of the crystalline units (Fig. 1F). The respiratory system is tubocanaliculate, with narrow and slender canals, ranging from 50 to $80 \mu \mathrm{m}$ in wide.

Comparisons and Discussion: Structural characters exhibited by eggshells described above are consistent with three oospecies of Megaloolithus: M. jabalpurensis, M. dhoridungriensis and $M$. mamillare. The Indian oospecies $M$. dhoridungriensis differs from our specimens by showing cylindrical-shape shell units, whit a H/W ratio of 2.7 (Mohabey, 1998). M. jabalpurensis and M. mamillare share several structural characters (Vianey-Liaud et al., 1994, $2003)$, only differing in the size of the egg $(15 \mathrm{~cm}$ and $20 \mathrm{~cm}$ in diameter, respectively), the eggshell thickness ( $2.3 \mathrm{~mm}$ in $M$. jabalpu- rensis and $2.1 \mathrm{~mm}$ in $M$. mamillare) and the $\mathrm{H} / \mathrm{W}$ ratio (2.45 in M. jabalpurensis and 2.1 to 2.2 in M. mamillare). Given that the studied oological material exhibits sub-spherical eggs of $20 \mathrm{~cm}$ in diameter, $1.9 \mathrm{~mm}$-thick eggshell, and $\mathrm{H} / \mathrm{W}$ ratio of 2 , it is attributed to the oospecies $M$. mamillare.

Moratalla $(1993,1998)$ described very scarce remains attributed to $M$. cf. mamillare in the Compuertas locality. The author stated that the recovered eggshells were badly preserved, obscuring several features. However, he noted that the thin eggshells collected in the locality exhibited compact and nodular ornamentation and nonfused shell units. Although we had not the chance to analyze this egg material directly on first-hand examination, all evidence point that the abovementioned characters described in the eggshells from the Compuertas locality fit with those of the oospecies $\mathrm{M}$. mamillare. Accordingly, we tentatively assign the oological remains of this locality to $M$. mamillare.

\section{Megaloolithus baghensis Khosla and Sahni 1995}

Diagnosis according to Fernández and Khosla (in press): Spherical eggs 140-200 mm in diameter; nodes ornamentation, eggshell $1.0-1.70 \mathrm{~mm}$ thick; average node diameter about $0.60 \mathrm{~mm}$; fanshaped spheroliths distinct or even partially fused; height/width ratio 2.32:1; pore subcircular to elliptical; swollen-ended, variably spaced basal caps $(0.2-0.3 \mathrm{~mm}$ in diameter).

Synonymies: Megaloolithus pseudomamillare from Suterranya-1 locality; Vianey-Liaud and López-Martínez (1997)

Megaloolithus trempii from Orcau, Suterranya, Vicari, Llabusta, and Fontllonga L localities; Moratalla (1998)

Megaloolithus cf. mamillare from the Suterranya and Orcau localities; Moratalla (1993, 1998)

Megaloolithus sp.; Vila et al. (2011)

Localities, stratigraphic range, and age: This Megaloolithus ooespecies is represented by eggs at Suterranya- 1 and by scattered eggshells at the Orcau-1, Orcau, Llabusta, Vicari, Suterranya, Fontllonga L, Barranc de la Boïga, Molí del Baró-1, Serrat del Rostiar-2, Camí del Soldat and L'Espinau localities. The Suterranya-1 localitiy is found on top of the Arén Sandstone Formation; the Orcau, Llabusta, Vicari, and Suterranya are found in the "grey unit" of the Tremp Formation; the Fontllonga L, Barranc de la Boïga, Molí del Baró-2, Serrat del Rostiar-2, Camí del Soldat and L'Espinau localities are located in the "lower red unit" of the Tremp Formation. Late Maastrichtian.

Material: see Appendix 1.

Description: complete eggs from Suterranya-1 and Suterranya localities are sub-spherical in shape. The smallest egg is $15-18 \mathrm{~cm}$ in diameter, while the largest is $21-23 \mathrm{~cm}$, and the eggs of Suterranya are about $21 \mathrm{~cm}$ in diameter (Moratalla, 1993). The outer surface of the shell is covered of coalescent rounded nodes ranging from 0.2 to $0.6 \mathrm{~mm}$ in diameter. Nevertheless, most part of the shell surface consists in flat areas and isolate nodes (Fig. 1G). Pore opening are $0.1-0.2 \mathrm{~mm}$ in diameter frequently located at the flattered surfaces. The eggshell thickness ranges from 1.12 to $1.85 \mathrm{~mm}$, with an average of $1.39 \mathrm{~mm}$. Eggshell units are broad fan-shaped (H/W ratio about 1.9), frequently fused with adjacent ones, and showing irregular morphology in their upper part (Fig. 1G). In radial thin section, the pore channels are narrow and straight (75-90 $\mu \mathrm{m}$ - width), corresponding to tubocanaliculate pore system. Growth lines appear slightly arched from the base to the top of the shell units.

Comparisons and Discussion: The oological material described above resembles $M$. aureliensis oospecies in the ornamental patterns, and $\mathrm{H} / \mathrm{W}$ ratio. However, this material is somewhat thicker 
than M. aureliensis (1.1-1.9 $\mathrm{mm}$ and $0.8-1.4 \mathrm{~mm}$, respectively). In addition, they differ in the shape of shell units, being more irregular in the studied material than that of M. aureliensis. M. baghensis also share several features with the studied material. For instance, the range of shell thickness of M. baghensis (1-1.7 mm; Mohabey, $1998)$ is similar to that that of our specimens (1.1-1.9 mm-thick). Both ootaxa exhibit similar size of node $(0.65 \mathrm{~mm}$ in diameter in M. baghensis and $0.5 \mathrm{~mm}$ in studied material) and pore apertures ( $0.15 \mathrm{~mm}$ in diameter in M. baghensis and $0.1-0.2 \mathrm{~mm}$ in studied material). Therefore, the oological remains described in the abovementioned localities are attributed to the oospecies M. baghensis.

Moratalla $(1993,1998)$ reported a new oospecies named Megaloolithus trempii in the Orcau, Suterranya-1, Vicari, Llabusta, and Fontllonga L localities of the Tremp and Àger basins. A recent revision of this ootaxon reveals identical microstructural characters (e.g. shell thickness, ornamental pattern, shape of shell units) than those of Megaloolithus baghensis, and hence both oospecies should be synonymised. The eggs sizes reported by Moratalla $(1993,1998)$ are slightly larger than those described in the diagnosis, albeit this can be explained as the result of a tangential-view section of the eggs or even due to regional tectonic deformation of the eggs (see Vila et al. 2010). Thus, the occurrence of M. baghensis in the Moratalla's $(1993,1998)$ localities is here stated. Moratalla (1993, 1998) also reported the presence of $M$. cf. mamillare in the Orcau and Suterranya localities. On the base of descriptions given by the author, we note that all characters (such as the ornamentation composed of rounded nodes and flatted surfaces, irregular shell units, and partially fused shell unit) fit with the oospecies M. baghensis. Therefore, we propose to synonymize the material referred to $M$. cf. mamillare in these localities with M. baghensis. Similarly, Vila et al. (2011) reported an egg and eggshell fragments attributed to Megaloolithus sp. from the J-BAR01 and E-MUN06 localities, respectively, in the Vallcebre Syncline. We re-examined the material concluding that they can also be attributed to M. baghensis because they show a surface covered with coalescent nodes, partially fused short fan-shaped shell units, undulating growth lines, and relatively thin eggshells $(0.7-0.9 \mathrm{~mm}$-thick).

\section{Appendix 2 references}

Elez, J., López-Martínez, N. (2000): Interrelationships between growth of mineral phase and pore system in dinosaur eggshells. In: Bravo, A.M., Reyes, T. (eds.), Extended Abstracts First International Symposium on Dinosaur Eggs and Babies, Isona, pp. 43-50.

Fernández, M.S., Khosla, A. (2015): Parataxonomic review of the Upper Cretaceous dinosaur eggshells belonging to the oofamily Megaloolithidae from India and Argentina. Historical Biology 27(2), 158-180. doi:
10.1080/08912963.2013.871718.

Garcia, G., Vianey-Liaud, M. (2001): Nouvelles données sur les coquilles d'oeufs de dinosaures Megaloolithidae du Sud de la France: systématique et variabilité intraspécifique. Comptes Rendus de l'Académie des Sciences Paris (IIA) 332, 185-191.

Khosla, A., Sahni, A. (1995): Parataxonomic classification of the Late Cretaceous dinosaur eggshells from India. Journal of the Palaeontological Society of India 40, 87-102.

Mohabey, D.M. (1998): Systematics of Indian Upper Cretaceous dinosaur and chelonian eggshell. Journal of Vertebrate Paleontology 18, 348-362. doi: 10.1080/02724634.1998.10011063.

Moratalla, J.J. (1993): Restos indirectos de dinosaurios del registro español: Paleoicnología de la Cuenca de Cameros (Jurásico superior-Cretácico inferior) y paleoología del Cretácico superior. Unpublished Doctoral Thesis, Universidad Autónoma de Madrid, Madrid, 286 p.

Moratalla, J.J. (1998): Spanish dinosaur eggs. In: A.M.G. de Carvalho, A.M. Andrade, V.F. dos Santos, J. Cascalho, R. Taborda, (eds.), I Encontro Internacional sobre Paleobiologia dos Dinossáurios. Museu Nacional de História Natural, Lisboa, pp. 26-35.

Sellés, A. G., Bravo, A.M., Delclòs, X., Colombo, F., Martí, X., Ortega-Blanco, J., Parellada, C., Galobart, À. (2013): Dinosaur eggs in the Upper Cretaceous of the Coll de Nargó area, Lleida Province, south-central Pyrenees, Spain: Oodiversity, biostratigraphy and their implications. Cretaceous Research 40 , 10-20. doi: 10.1016/j.cretres.2012.05.004

Simón, M.E. (2006): Cáscaras de huevos de dinosaurio de la Formación Allen (Campaniano-Maastrichtiano), en Salitral Moreno, provincia de Río Negro, Argentina. Ameghiniana 43, 513-528.

Vianey-Liaud, M., Garcia, G. (2003): Diversity among North Africa dinosaur eggshell. Palaeovertebrata 32, 171-188.

Vianey-Liaud, M., López-Martínez, N. (1997): Late Cretaceous dinosaur eggshells from the Tremp Basin (Southern Pyrenees, Lleida, Spain). Journal of Paleontology 71, 1157-1171.

Vianey-Liaud, M., Zelenitsky, D.(2003): Historical and new perspectives on the parataxonomy of fossil eggs. Palaeovertebrata 32, 189-195.

Vianey-Liaud, M., Mallan, P., Buscail, O., Montgelard, G. (1994): Review of French dinosaur eggshells: morphology, structure, mineral and organic composition. In: Carpenter, K., Hirsch, K.F., Horner, J.R. (eds.), Dinosaur Eggs and Babies. Cambridge University Press, Cambridge, pp. 151-183.

Vianey-Liaud, M., Khosla, A., Garcia, G. (2003): Relationships between European and Indian dinosaur eggs and eggshells of the oofamily megaloolithidae. Journal of Vertebrate Paleontology 23, 575-585. doi: http://dx.doi. org/10.1671/0272-4634(2003)023[0575:RBEAID]2.0.CO;2

Vila, B, Jackson, F.D., Fortuny, J., Sellés, A.G., Galobart, À. (2010): 3-D Modelling of megaloolithid clutches: Insights about nest construction and Dinosaur behaviour. PLoS ONE 5(5), e10362. doi: 10.1371/journal.pone.0010362

Vila, B., Riera, V., Bravo, A.M., Oms, O., Vicens, E., Estrada, R., Galobart, À. (2011): The chronology of dinosaur oospecies in southern Europe: refinements from the Maastrichtian succession of the Eastern Pyrenees. Cretaceous Research 32, 378-386. doi: 10.1016/j.cretres.2011.01.009.

Villalba-Breva, S., Martín-Closas, C. (2012): Upper Cretaceous paleogeography of the Central Southern Pyrenean Basins (Catalonia, Spain) from microfacies analysis and charophyte biostratigraphy. Facies 59, 319-345. doi: 10.1007/s10347-012-0317-1.

Zhao, Z. (1979): Discovery of the dinosaurian egg and footprint from Neixiang County, Henan Province. Vertebrata PalAsiatica 17, 304-309. 